\title{
MISREPRESENTATION, WARRANTY AND ESTOPPEL
}

\author{
P. S. ATIYAH*
}

Few legal concepts are as basic, and as ill-defined, as representation, warranty, and estoppel. Professor Atiyah conducts an examination of the nature of these concepts, as well as their interrelation. The nature of a representation, the nature of a warranty, and the nature of the distinction between misrepresentation and warranty are instructively analyzed in the first part of the article. In the second part, Professor Atiyah investigates the nature and functions of the doctrine of estoppel by representation, and discusses the relations between repre. sentation, warranty, and estoppel.

The law relating to misrepresentation occupies a hazy and undefined area generally thought to lie along the boundaries of tort and contract. Some of the subject-that covered by 'estoppel by representation'-is also thought to have some connections with, or even to be an integral part of, the law of evidence. As is so often the case in the law, the principles and rules themselves give an appearance of order and relative certainty which in practice is only achieved by prejudging many of the crucial issues in the initial classification of the problem. If we once place our fact situation under the heading 'warranty' or 'contract' or 'estoppel' or 'deceit' or 'negligence', the result often appears to be dictated inexorably by the legal principles applicable to that category. So often, however, the real difficulty is to know what determines the initial classification. Consider, for instance, this basic situation, which is to be found in a large number of actual cases:

A misrepresents certain facts to $B$; relying on this representation $B$ enters into a contract with $C$, and later suffers loss through C's failure to perform. ${ }^{1}$

These facts carry no legal classification on their face. And yet the result of any claim made by $B$ against $A$ may well turn on whether this is classified as a contractual situation in which case A may be held to have 'warranted' the facts he has stated, or a tort situation in which A may be liable if he has been fraudulent or negligent, or even as an estoppel situation in which case the law is still more obscure. This being so it seems important that we should try to probe behind these legal labels to see if there are factors which help us in making our initial classification.

In this article I want, therefore, to analyse the nature of liability for misrepresentation in the modern law in order that the policy issues can be more clearly seen, unobscured by the technical classifications and concepts which, as lawyers, we impose on the factual situations we have to deal with.

\section{Misrepresentation and Warranty}

It is necessary here to distinguish two situations, one of which is familiar to all students, but the second of which covers ground of which discussion is rare.

* M.A., B.C.L., Professor of Law, Australian National University.

1 This statement of facts is true of the following cases:

Pasley v. Freeman (1789) 3 T.R. 51 (liability for deceit); Hedley Byrne v. Heller [1964] A.C. 465 (negligence); and Wells v. Buckland Sand Ltd. [1965] 2 Q.B. 170 (warranty). 


\section{A. Representation inducing contract between parties thereto}

1. Representation or Warranty: the nature of the question

The first situation is the familiar case of a contract between $\mathbf{A}$ and $B$ which is preceded by a misrepresentation made by A to B. As every law student knows the question which arises here is whether the representation is a 'warranty' or a 'mere representation'. In the great majority of cases the purpose of asking this question is to determine whether the representor is liable in damages to the representee. At common law, certainly between about 1700 and 1963, the position was that the representor was always liable in damages if he was fraudulent, and was sometimes liable even where he was not fraudulent. If we leave fraud out of account, the difficulty was to distinguish those cases in which the representor was to be held liable from those where he was not. This distinction was expressed by using the notion of 'warranty'. If the representor warranted the truth of the facts he stated then he was liable (even absent fraud); otherwise, not. However, it will be seen that there is an element of circularity in legal reasoning here. The word 'warranty' may be a convenient label to attach to the one fact situation and not the other; to say that ' $A$ warranted the truth of the facts' is a simple shorthand way of expressing the legal conclusion that $A$ is liable in damages if the facts he stated are untrue. But if this is why we use the word 'warranty' it will be seen that we must first decide if there is liability in damages before we can apply the label. There is then a danger that we are reasoning in a circle, i.e.

(1) whether $A$ is liable depends on whether he gave a warranty; and (2) whether the representation was a warranty depends on whether $\mathrm{A}$ is liable.

In either event we have so far not even begun to answer the ultimate question. If we start with question (1), the ultimate question is whether the representation is a warranty, while if we start with question (2) the ultimate question is whether $A$ is liable. In fact, as is well known, the Courts start with question (1) and ask whether the representation is a warranty. How then is this question to be answered? Again, as is well known, the Courts treat this question as depending on the intention of the parties. In Heilbut, Symons \& Co. v. Buckleton ${ }^{2}$ the House of Lords treated it as having been settled by Lord Holt that 'An affirmation at the time of the sale is a warranty, provided it appear on evidence to be so intended'. ${ }^{3}$ It has often been pointed out that Lord Holt never said anything of the kind in the decisions to which reference was made in Heilbut, Symons \& Co. v. Buckleton, ${ }^{4}$ namely Crosse v. Gardner ${ }^{5}$ and Medina v. Stoughton. ${ }^{6}$ Indeed Lord Holt is reported to have said in both these cases that a buyer could sue a seller of goods upon a 'bare affirmation'; and since he reported both decisions himself it is somewhat remarkable that he omitted to mention

${ }^{2}$ [1913] A.C. 30.

3 Per Lord Moulton, at 49.

4 Nor indeed anywhere else so far as is known.

5 (1689) Holt K.B. 5; 3 Mod. Rep. 261; 1 Show. 68; Carth. 90; Comb. 142. None of the reports says anything about 'intent'.

6 (1700) Holt K.B. 208.

7 In Medina v. Stoughton. Holt's own report states (of an action for misrepresentation by a seller of a lottery ticket that he was the owner of the ticket) 'the bare affirming it to be his amounts to a warranty'. In Crosse v. Gardner, only the report in Carth. 90 contains the reference to 'bare affirmation'. 
the requirement of 'intent' if, as the House of Lords thought over 200 years later, Lord Holt regarded this as the essential element of a warranty. It is, of course, well-known, that this requirement of 'intent' was a gloss on Holt's own decisions which derives from the judgment of Buller, J. in Pasley v. Freeman. ${ }^{8}$ But what has not often been observed is the precise context in which this remark appears. The requirement of 'intent' is mentioned by Buller J. in that part of his judgment in which he is explaining away the old decision in Harvey $v$. Young. ${ }^{9}$ In that case the plaintiff had bought a lease from the defendant for $£ 150$. He later tried to resell the lease and found he could not get even $£ 100$ for it. He then sued the seller alleging that the seller had affirmed the lease to be worth $£ 150$. The action was dismissed on the ground that this was a 'bare assertion' and that it was the 'plaintiff's folly to give credit to such assertions', but the Court added that the defendant would have been liable if he had warranted the lease to be of the value stated. In dealing with this sort of situation it is quite understandable that Buller J. should have used the language of 'intent'. Clearly, assertions by a seller of the value of what he sells are normally disregarded by buyers (and therefore by the Courts) as mere 'sales-talk'. Even today the decision in Harvey v. Young does not look at all unreasonable. In this connection it is interesting to note that although representations in contracts of sale of goods are treated as warranties in America, both the U.C.C. ${ }^{10}$ and the Uniform Sales Act ${ }^{11}$ which it replaced, specifically provided that assertions about value were not to be construed as warranties. Nevertheless, it is also clear that in some circumstances it might be just to regard an affirmation of value as amounting to a warranty, e.g. where the seller is an expert and the buyer makes it plain that he regards the seller's statements as binding commitments. This distinction is not unnaturally expressed by saying that in this situation the seller 'intends' his affirmation to be a warranty. But it does not at all follow that representations as to matters of ordinary fact within the peculiar knowledge of the seller should only be treated as 'warranties' if there is positive evidence of an intention to that effect. Nothing that Holt or Buller said could possibly justify such a conclusion.

It is possible that in introducing the requirement of intent into the notion of warranty, Buller J. may also have been influenced by another fact. At the time of Holt's decisions, a claim for breach of warranty was prosecuted in the form of an action on the case in the nature of deceit. In modern parlance this smacked more of tort than contract, and indeed in modern times the action of deceit is a purely tortious remedy. But shortly before Pasley v. Freeman it had been decided that a claim for breach of warranty could be brought in assumpsit. ${ }^{12}$ This meant that warranties had, procedurally at least, shifted over to the law of contract at the time when Pasley v. Freeman was decided.

This little excursion into history may not be thought of great moment,

- (1789) 3 T.R. 51.

- (1603) Yelv. 21.

10 U.C.C. 2-313.

"Sect. 12

12 Stuart v. Wilkins (1778) 1 Doug. K.B. 18. Buller. J. was a party to this decision which he regarded as merely confirming long-standing practice. Yet at about the same time Blackstone regarded warranties as so similar to representations that he thought there could be no warranty of a future fact; see $3 \mathrm{Bl}$. Comm. 165 . 
for modern doctrine is settled clearly enough. And most probably it matters little in any case for 'intent' to warrant is readily found by the Courts when a seller makes statements of matters peculiarly within his knowledge. But the slender historical foundation on which the requirement of 'intent' rests is still of interest if only because it shows that there is nothing in the law of nature which places 'warranty' in the area of contract rather than tort law.

The question which I now want to pursue is how far liability for breach of warranty is, even today, genuinely contractual. English lawyers are by now imbued with the idea that a statement of fact inducing a contract may be treated as a warranty and thereby become in a sense 'incorporated in the contract'. But the language of 'incorporation' also has its dangers, for two related reasons. First, because incorporation' looks like a factual concept whereas it is in truth a legal concept expressing (like the word 'warranty' itself) a legal conclusion from a factual situation. And secondly because when 'the contract' is in writing there is a tendency to assume that 'incorporation' means physical incorporation in the written document itself. It is needless to dwell on the illogicalities of all this; needless to stress that the contract' is not the physical document in which terms are written down, but the rights and duties imposed by the law; needless to point out that the whole treatment of the idea of 'incorporation in the contract' was greatly influenced by the policy of the Courts to prefer written to oral evidence. It suffices to point out that the idea of 'incorporating' a representation in a contract states a legal conclusion rather than a fact.

This is not to say that physical incorporation of a representation in a written contract is (or has ever been) irrelevant to the ultimate legal question; quite the reverse, for as a matter of fact, the representor will almost invariably be held liable as for a warranty in this situation. Thus physical incorporation is usually a sufficient condition of legal incorporation; but it is not a necessary condition. It is in this latter respect that the law has gradually been relaxed for at one time the combined effect of the Statute of Frauds and the parol evidence rule was almost to elevate physical incorporation into a necessary condition of legal incorporation.

I return then to the question whether liability for breach of warranty is 'truly' contractual. This question is not as meaningless or futile as it may seem at first sight. For if there is something 'truly' contractual about warranties we would have a firm basis for the treatment of all misrepresentation. We would then only need to enquire if a misrepresentation is genuinely contractual in nature in order to decide if it is to be treated as a warranty or relegated to the field of tortious liability.13 If, however, it should transpire that warranties differ from other forms of contractual liability and are merely treated as though they were (while not in fact being) contractual then this easy approach will be barred.

This method of approach requires us to come perilously close to indulging in the somewhat unfashionable exercise of looking for the

13 This assumes that one accepts the basic starting point that contract-type liability is normally 'strict' while tort-type liability is normally fault based. Much could be written about the desirability of this distinction. but it is unnecessary to pursue this here in view of my conclusions on the question raised in the text. 
'essence' or 'basis' of 'truly' contractual obligations. But we can safely by-pass these difficulties by taking as a starting point the assertion that all contractual obligations are either representations or promises, and that the typical or paradigm contractual obligation is a promise. In America it is customary to define contracts in terms of promises. In England it is perhaps more usual to define contracts in terms of agreements, but even this sort of definition usually imports that the parties are agreeing about their future behaviour. Parties often agree about a state of facts, ${ }^{14}$ but nobody would think of such an agreement as being remotely like a contract. The question, then, is in what respects does a warranty resemble, and in what respects, differ from a promise?

\section{The role of consent or agreement as a basis for liability}

The first and obvious question is whether, and if so to what extent, promises and warranties are based on the consent or will of the parties, or at least of the defendant? At first sight it might seem that both promises and warranties are based on the will or agreement of the parties. So far as ordinary contractual promises are concerned, traditional dogma asserts that liability here is rested on the voluntary assumption of liability, on the free choice of the parties; so far as warranties are concerned, the position seems to be the same since no representation is a warranty unless 'intended' as such.

This approach has, however, been strenuously criticised by American lawyers. In 1911 Williston $^{15}$ attacked the notion that a warranty comprising a bare representation is contractual, and argued that a representor, unlike a promisor, never intends to impose liability on himself merely by affirming a state of facts to be so. The liability is imposed by the law. Other American academics have generally followed Williston. Prosser, ${ }^{16}$ for instance, points out that the imposition of liability on a seller of goods by way of 'implied terms' even where nothing is said, is also confirmation of the fact that the liability is imposed by law and not based on agreement of the parties.

The American position is more easily defensible because the requirement of 'intent' for warranty liability has never struck root there in the way that it has in England. It is normally understood to mean that the representor must have 'intended' to affirm his statement as a fact and not (for instance) merely to have proffered an opinion on facts not known to him, or to have been indulging merely in sales talk.

In order to consider the validity of the American view it now becomes necessary to look more closely at this requirement of 'intent'. What precisely is it that the parties, or the representor, must 'intend'?17 Buller J's formulation which was approved (though attributed to Holt) in Heilbut, Symons \& Co. v. Buckleton is merely that the representation must be 'intended' to be a warranty. Now the result of treating a representation as a warranty is to impose on the representor strict liability for the consequences of the untruth of the statement. To 'intend' a representation to be a warranty therefore must be to 'in-

\footnotetext{
14 Perhaps the most common form of agreement found in the Law Reports is agreement by one judge in the judgment of his brother judge. Anything less like a contract it would be hard to find.

is Liability for Misrepresentation, (1911) 24 Harv. L.R. 415. And see also Williston on Contracts, 3rd ed. 1970, Vol. 12, §1505.

16 Prosser on Torts, 3rd ed., at 724.725.

17 I need not pursue the complication that it is the appearance rather than the reality of intent which matters, see Denning L.J. in Oscar Chess v. Williams |1957] 1 W.L.R. 370, 375.
} 
tend to accept strict liability for the consequences of the statement being untrue'. For instance if a representor says: ' $I$ will be answerable for the consequences if the representation is untrue', the requisite 'intention' will be present.

It will, however, be seen that in this situation the representor is in fact making a promise, and not merely representing certain facts to be true. Such a promise would more commonly be found over and above a representation, rather than standing alone. ${ }^{18}$ Thus the representor may first make a representation and then promise to be answerable if it is untrue. Corbin, indeed, argues that every warranty is really a promise to indemnify against loss, ${ }^{19}$ but this seems to be the legal effect rather than the intent of a warranty. The distinction emerges where the representee does not believe what the representor says: in that case he has no ground of complaint if the representor was merely making a statement of fact, although that statement might otherwise have been treated as a warranty. But if the representor really has promised to be answerable for the consequences, non-belief in the facts is immaterial. ${ }^{20}$ If, however, no such express promise is made, the representation is still often treated as carrying with it such an implied promise'. The question now is whether such an 'implied' promise is a genuine implication or a fiction?

It is at this point that the current American view seems to be too simple: the attempt to separate liability for breach of promises as based on agreement from liability for breach of warranty as imposed by law independently of agreement is surely too black and white. The true view surely is that (i) both types of liability are in the last analysis imposed by the law; that (ii) these liabilities are imposed for a variety of reasons; that (iii) one such reason is frequently that the defendant has to some degree consented to or agreed to bear the liability; that (iv) this element of consent or agreement plays a larger role in some cases and a smaller role in other cases; that (v) typically, it plays a larger role in liability for promises than liability for representations; but the magnitude of the part played by consent or agreement is dependent on many other factors besides the distinction between promises and warranties. Hence it will certainly be found that there are some cases of breach of warranty which are based on a greater degree of agreement or consent than some cases of breach of promise. I proceed to enlarge on these points.

\section{i. Both types of liability imposed by law}

It is surely unnecessary at this day and age to labour this point. Even in a legal system where full recognition is given to the private autonomy of parties to make their own contracts, it is the law which creates legal rights and duties.

\section{ii. Liabilities imposed for a variety of reasons}

Here again, the point hardly needs labouring. Throughout the

10 It is possible for a person to promise to be answerable in the event of certain facts turning out to be untrue without representing the truth of these facts. For instance, an agent may induce a third party to contract with him by saying: 'I do not assert that I have my principal's authority; but I will be answerable for the con. sequences if I have not.' See Halbot v. Lens [1901] $1 \mathrm{Ch}$. 344, 351. But although this is possible, a promise to be answerable for the truth of certain facts would more normally be based on a representation that those facts are 80 .

19 Corbin on Contracts, Vol. $1, \$ 14$

${ }^{20}$ See Leggo v. Brown \& Dureau Ltd. (1923) 32 C.L.R. 95. 
whole field of civil liability, from tort liability for personal injuries through breach of contract and breach of trust, legal rights and duties are imposed for a complex mixture of reasons.

\section{iii. Consent or agreement as a relevant factor}

Again, a simple point. That consent or agreement is one relevant factor in the imposition of civil liability is surely beyond argument.

\section{iv. Consent or agreement plays a varied role}

It is perhaps here that we begin to approach more difficult terrain. The traditional distinction between contract and tort which is so built into the ways of thought of the modern lawyer, is based on the supposition that contractual duties derive from consent while tort duties are imposed by law. This distinction lay at the root of Winfield's wellknown definition of tort liability. ${ }^{21}$ Yet it is surely clear that what we have in fact is not a sharp dividing line between voluntarily accepted duties and legally imposed duties, but an enormous variety of circumstances in which consent or agreement plays a more or less prominent part as a ground for ultimate decision. Even in simple contract cases there is, for instance, a considerable chasm between (say) an action to recover an agreed price and an action for damages for breach of contract. In the former case the whole claim is an attempt to compel the defendant to pay what he has promised, though even here the requirement of consideration is a reminder that consent or agreement to be bound is not a sufficient basis for imposing liability without reference to other factors. But an action for damages for breach of contract is to a much less extent based on the agreement or consent of the promisor. A seller of goods promises to deliver the goods; but he does not usually make an express promise to pay damages if the goods are not delivered. But this case also illustrates that the distinction between a genuine 'implied' promise and an obligation imposed by law is similarly a distinction which cannot be maintained by any hard and fast line. Although a seller usually makes no express promise to pay damages for non-delivery it is arguable that a seller in a modern legal system must know that a liability to pay damages is a common result of failure to deliver, and that in a sense he may therefore be taken to 'agree' or 'consent' to this result. Even here it is clear that there will be wide variations in the reality of this consent or agreement. At one extreme there may be a case in which a seller acts in the ordinary course of business and is (perhaps) warned by the buyer that he will be held responsible for non-delivery; here the seller may come very close to promising to pay damages for nondelivery. At the other extreme there may be a case in which a private seller who has no knowledge or understanding of the law is held liable for consequential damage. In such circumstances the agreement or consent of the seller plays little part in the ultimate result. Indeed its role is merely as a factor helping to set the stage, the ultimate result of which is prescribed for reasons of policy and justice independent of agreement or consent. There is little difference between this type of situation and (say) the tortious liability of an occupier of premises to his visitors. 
[VOL. IX

v. Typically, consent plays a larger role in imposing liability for promises than for misrepresentations

Undoubtedly promises differ from misrepresentations in a number of important respects which bear on the reasons for imposing liability, but the distinction cannot be wholly explained in terms of the role played by consent or agreement. We have already seen that the part played by consent or agreement in imposing liability for promises varies enormously from case to case. But the same is also true of liability for misrepresentations. For example a business seller who makes positive assertions of fact about the goods he sells may well appreciate that such assertions may amount to warranties and therefore know that he is assuming, and be willing to assume, such liability in making the representation. At the other extreme a person may make a relatively casual misrepresentation without appreciating or anticipating that it will have any legal repercussions on any resulting contract.

Moreover, in the typical warranty case-i.e. warranty of quality in contracts of sale of goods-the distinction between warranty and promise often turns merely on whether the sale is of specific or unascertained goods. In a sale of unascertained goods to be acquired by the seller, statements about the quality of the goods can only be part of the promise: the seller promises to deliver goods of a certain quality. In a sale of specific goods, however, the self-same statement may amount to a warranty. It seems strange, therefore, to insist that in the former case the liability is self-imposed while in the latter it is imposed by law. ${ }^{22} \mathrm{~A}$ similar objection arises in other cases from the fact that a seller may be unable to deliver the goods he has promised to sell because of a certain state of facts which he has misrepresented. It seems wholly artificial in such a situation to say that the liability for non-delivery is contractual and arises from consent, while any liability for misrepresentation cannot arise from consent.

So far it may appear that there is little distinction between the role of consent or agreement in liability for promises and for representations. But this would not be the correct conclusion. As I have already suggested, the typical case of breach of promise does differ from the typical case of liability for representations. First, the typical promise looks like a binding committment, and the typical promisor must normally realize that he is undertaking liabilities which may in the last resort be legally enforced against him. But it is much more doubtful whether this can be said of the 'typical representation', or indeed, whether there is such a thing as a 'typical representation'. This becomes even more obvious when we pass to cases where a representation is made which does not induce any other transaction between representor and representee. After all a representation is merely a statement of fact, and statements of fact are constantly being made by all people in the course of daily conversation without any thought or intention of assuming any legal obligations whatever. And this is even true of many statements in business contexts. Consider,

22 I do not assert that there is no relevant distinction between a sale of specific and a sale of unascertained goods. In the former case the buyer may have the opportunity of examining the goods before he buys and therefore a statement as to quality etc. may not be treated as a warranty, at least according to prevailing English doctrine, (though it is probably otherwise in America). But in a sale of unascertained goods the buyer must perforce trust to the seller's statements and therefore statements about quality will be almost inevitably construed as promises. 
for instance, the familiar action for breach of warranty of authority. In Cherry and McDougal v. Colonial Bank of Australasia ${ }^{23}$ the defendants were company directors who appointed $C$ as a manager and notified their bankers by letter that $\mathrm{C}$ had authority to sign cheques. C overdrew the company's bank account without the authority of the shareholders as required by the company's regulations. Being unable to recover against the company, the bank sued the directors for breach of implied warranty of authority: in notifying the bank of the appointment of $C$ they had represented that $C$ had the authority of the company to borrow. The defendants' counsel protested, not unjustly, that they had no intention whatever of incurring any liability to the bank:24

'This letter' he said 'contained no words of contract, it stipulates for no consideration, and shows no intention on either side to make a contract, yet the action brought is founded on a contract, and no contract is proved.'

The objection did not prevail ${ }^{25}$ for the Court held that the jury were entitled to 'imply a warranty' to the Bank, on the part of the defendants, that $C$ had authority to bind the company so as to make them responsible to the Bank for the advances on the cheques. ${ }^{26}$

The same is true of any number of cases of misrepresentation which are enforced by way of estoppel where the representor probably had no intention or thought of binding himself to any legal liability by his representations.

Another reason why a representation is not so often or typically intended as a binding commitment when compared with a promise is that a promise is only one possible way of declaring the intentions of the promisor. A person may intend to conduct himself in a certain way and may declare that intention to another who may rely on that statement of intention; yet the party making the declaration will not be liable if he changes his mind.27 To say that you intend to do something is not necessarily the same thing as to promise to do it, though doubtless in appropriate circumstances a declaration of intention may reasonably be understood as a promise. But a representation of existing fact differs in this way from a statement as to the future. The former has to do double service within the same linguistic framework; an ordinary statement of existing fact corresponds, in relation to future facts, both with mere statements of intention and with promises. To some extent, no doubt, a statement of fact may be made in the more guarded language of 'opinion' and this perhaps corresponds more closely with mere declarations of intent, while positive assertions of fact correspond more with promises. But it would be unrealistic to assume that in ordinary speech a representor of facts, even when he makes a positive assertion as opposed merely to stating an opinion, intends to take upon himself any sort of commitment; while a person who makes a promise, as opposed to merely declaring his intention, clearly does normally accept a commitment.

3. Other Distinctions between Representations and Promises

It would be misleading to think that the distinction between a state-

23 (1869) L.R. 3 P.C. 24.

24 Id. at 28 .

25 Yet in other cases this sort of argument has been accepted as conclusive that there can be no warranty. type liability, see e.g. Low v. Bouverie [1891] $3 \mathrm{Ch} .82$.

- Id. at 31.

"7 See Maunsell v. Hedges (1854) 4 H.L.C. 1039; Wells v. Matthews (1914) 18 C.L.R. 440. 
ment of fact and a promise turns only on the extent to which any resultant liability is based on the consent or agreement of the defendant. There are other important distinctions which must surely have had some bearing on the differing degrees to which legal liability is in fact imposed in the two cases.

First, and perhaps most important, promises usually give rise to expectations while statements of fact are less likely to do so. Allied to this is the fact that promises are more likely to induce conduct in reliance than representations of fact; moreover a promise is usually a better reason for relying on another than a representation. One of the major issues in determining whether the law should give relief for a misrepresentation is whether the representee was entitled to act in reliance on the representation. The problem is often said to be whether the representee acted reasonably in reliance on the representation, but I believe this is too simple a view. It is one thing to say a person has acted reasonably in relying on a representation; quite another thing to say that he was entitled to rely on it so as to hold the representor liable for the consequences if the representation should be untrue. The difference is perhaps most marked in cases of representations or advice published to the world in the form of advice in newspapers etc., or the certificate of a company's auditors. It is often quite 'reasonable' to rely on such statements, but it does not follow that legal liability is or should be imposed where the statement is untrue. This problem is far less acute in the case of a promise, because a promise virtually invites reliance; moreover the gap between relying on a promise and being entitled to rely on it seems shorter than the corresponding gap in cases of misrepresentations.

These factual distinctions have led to important legal distinctions between promises and representations. One of the most significant distinctions is that actions for damages for breach of a promise are commonly brought on a purely executory transaction. The promisee does not have to show reliance on the promise, though in the absence of such reliance he will have to show consideration in the form of a counter-promise. But an action for a misrepresentation is almost invariably a claim for relief against the consequences of having acted upon the misrepresentation. This raises an issue of some importance in connection with the reform of the law, viz., whether a misrepresentation should be actionable even without damage caused by action in reliance. As we shall see later, where a misrepresentation is made which does not induce a contract between the parties, the misrepresentation is sometimes treated as a warranty by the Courts, and the consideration for this is the very action in reliance which leads to the damage. Proposals for the abolition of consideration as a requirement for the enforceability of a promise therefore raise the question whether a misrepresentation which gives rise to expectations should be actionable even if it has not been acted upon. I return to this point later.

But if there are important distinctions between representations and promises there are also many similarities. Perhaps the most obvious is that it is unfair and unreasonable to impose liability for either promises or misrepresentations which form part of ordinary social discourse. In the case of promises this is justified by holding that there is no 'intent to create legal relations'. In the case of misrepresentations 
it is justified by holding that there is no 'intent to warrant' or no 'duty of care'. These differing legal concepts obscure the fact that similar policy issues arise whether a case is classified as contract or tort, as an action for breach of warranty or negligent misrepresentation.

\section{B. Misrepresentation not inducing contract between parties thereto}

\section{Representation inducing contract with third party}

Where a misrepresentation is made by $A$ to $B$ and no subsequent contract is entered into between these parties the case looks at first sight as though the misrepresentation cannot be treated as a warranty at all. On the face of it, the situation does not look contractual, but (if wrongful at all) tortious. But if this situation had been characterised as tortious rather than contractual it would have followed that, at least until the Hedley Byrne case, ${ }^{28}$ the representor could rarely be liable unless he were fraudulent. And even since the Hedley Byrne case the representor could only be liable if he was held to be negligent. To impose strict liability on the representor it was necessary ${ }^{29}$ to treat the representation as a contractual warranty. But this of course gave rise to many difficulties. A representation standing alone does not look like a contract; it is hard to reconcile the treatment of such a representation as a contractual obligation with the traditional contract analysis of concepts such as offer, acceptance, bargain and so on. Above all it seems (at least to modern lawyers) difficult to find any consideration for the warranty.

But in fact these difficulties were overcome by the Courts, Starting with the great case of Collen v. Wright ${ }^{30}$ the Courts first recognized and then developed the possibility of treating a representation as a warranty even where the representation did not induce a subsequent contract between the parties. As we shall see the eventual developments of this principle enable strict liability to be imposed by the Courts for virtually any type of representation where justice and policy seem to demand this result.

In Collen v. Wright the plaintiff negotiated with the defendant who was the agent of a third party, for a lease of the third party's property. On the conclusion of the negotiations the plaintiff went into possession but the third party later repudiated the agreement and denied that his agent had any authority to make it. The plaintiff sued the third party for specific performance but lost his action because of the agent's lack of authority. He then claimed damages from the agent. It was not denied that the agent bona fide believed himself to have authority. In substance the claim was for damages on the ground that the agent had held himself out to be, or represented himself to be, agent of the third party with authority to enter into the agreement. But an action in tort for an innocent misrepresentation would have stood scant chance of success in 1857. The plaintiff therefore alleged

\footnotetext{
${ }^{21}[1964]$ A.C. 465.

29 Not of course logically necessary because there is nothing impossible about strict liability in tort. But when it is remembered that liability even for fraudulent misrepresentation (apart from contract) was only recognised in 1789 and for negligent misrepresentation in 1963, the practical possibility of the Courts holding a representor strictly liable in tort was and still is remote indeed.

30 (1857) 8 E.\&B. 647. There were already at this date some very strong dicta which favoured a wide view of warranty in Maunsell v. Hedges (1854) 4 H.L.Cas. 1039, 1055 and 1059-1060, though these seem to have been largely forgotten. In this case Lord St. Leonards even found a 'general principle' that 'a representation which is made as an inducement for another to act upon it, and is followed by his acting upon it, will, especially in such a case as marriage, be deemed to be a contract'.
} 
that the defendant's representation was a 'warranty'. And this claim was upheld by the Court of Exchequer Chamber.

It is not surprising that strict liability for representations standing alone should have first been recognized in the Collen v. Wright situation because this situation is very close to the traditional type of warranty. The representation did in fact lead to the making of a contract between the representor and representee and to that extent fell squarely within the older cases holding representations by sellers of goods to be warranties. There were, of course, two new factors in the case which caused problems: firstly, the agreement for the lease was void, and secondly the representor only entered into that agreement as agent. These factors cause some 'doctrinal' difficulty, particularly in relation to consideration. But they did not seriously trouble the Court, it simply being asserted that the plaintiff's entry into the main transaction was a sufficient consideration for the agent's warranty of authority.

What did trouble the Court more seriously was whether the plaintiff was justified in relying on the defendant's representation of authority. Having regard to the general common law attitude of 'caveat emptor' it could be (and indeed was) argued that the plaintiff should have enquired of the defendant's principal whether the defendant had the necessary authority, and that since he made no such inquiry he simply accepted the risk of absence of authority. This argument was accepted by Cockburn C.J. but he found himself in a minority of one; ${ }^{31}$ the majority took the more realistic view that the plaintiff was entitled to rely on the defendant's representation of authority, since the defendant of all people should have known the extent of his authority.

Collen v. Wright has fathered a considerable progeny. Amongst its descendants can be numbered many cases of collateral contracts. $A$ makes a representation to $B$. B, in reliance thereon, enters into a contract not with $A$ but with $C$. B can sue $A$ for breach of warranty so long as he can show an 'intent' to give a warranty or an animus contrahendi.32 But the two major developments in the principle of Collen v. Wright occurred in the early years of this century. In the first, the principle of the agent's warranty of authority was extended to cases where the representee was induced to act otherwise than by making a contract with the agent. And in the second, the whole doctrine cut loose from its moorings and ceased to be dependant on any question of agency.

\section{Representation inducing other forms of conduct}

\section{a. Breaking out of the Collen v. Wright situation}

In Starkey v. Bank of England ${ }^{33}$ the House of Lords decided that an agent could be liable for breach of warranty of authority to a plaintiff who did not enter into any contract with the agent but suffered loss through reliance on the agent's representation in some other way. In this case the Bank of England sued a firm of brokers who had in all good faith presented a forged power of attorney purporting to

\footnotetext{
31 Just as Grose J: had found nobody to agree with him in Pasley v. Freeman, supra, that the plaintiffs should not have relied on the defendants' statements but made their own enquiries.

32 See Wells v. Buckland Sand Ltd. [1965] 2 Q.B. 170.

${ }^{33}$ [1903] A.C. 114, approving Firbank's Executors v. Humphreys (1886) 18 Q.B.D. 54.
} 
authorize them to transfer certain consols. The Bank registered the transferee of the consols as the owner and he later transferred them to a bona fide purchaser for value. This purchaser was entitled, on well settled principles, to hold the Bank liable, and the Bank sought an indemnity from the brokers who had presented the forged power of attorney. The case was presented as one of a warranty by the brokers that they had the authority which they appeared to have under the power of attorney. The brokers, however, argued that the case differed from Collen v. Wright in that the Bank's loss derived from the fact that they had registered the transferee of the consols and not from any contract which they had made with the brokers. This distinction was rejected as 'absolutely immaterial'34 and the brokers were held liable for breach of warranty.

\section{b. The 'request' principle}

Two years later Sheffield Corporation v. Barclay ${ }^{35}$ came before the House of Lords. This case was very similar to that of Starkey v. Bank of England but it did not involve any question of agency at all. The defendants had accepted in good faith a certificate of Sheffield Corporation stock and a forged transfer as security for a loan. They later sent the certificate and transfer to the Corporation for registration; the transfer was registered and the defendants later sold and transferred the stock to a buyer who thus had a valid claim against the Corporation. The Corporation, also being liable to the true owner, sought an indemnity from the defendants. Thus in all essentials the facts were identical with those in Starkey's case except that the defendants had acted as principals throughout. What was alleged against them was that they had represented the transfer to be genuine and not that they represented themselves to have authority. It was thus not possible to treat the case as a simple case of breach of warranty of authority; but equally the plaintiffs could not succeed in a simple action for damages for misrepresentation having regard to Derry v. Peek, ${ }^{36}$ still fresh in the memory of the profession. It was, therefore, necessary to find a new principle to support the plaintiffs' action. This principle was found by the House of Lords in an old line of cases dating back to Adamson v. Jarvis in $1827 . .^{37}$ According to this principle, whenever one person "requests" another to do an act which is not manifestly illegal or tortious the former comes under an obligation to indemnify the latter against any loss which he may suffer in consequence. This principle is one of considerable interest and importance and deserves something of a digression. One of the most interesting features of this principle is that it is so little noticed in the books; ${ }^{38}$ the reason for this is doubtless that it is not at all clear to what branch of the law these cases really belong.

They hardly look like cases of tort, and are certainly not treated as such in the tort books. But they do not look very like ordinary

\footnotetext{
34 [1903] A.C. 117, per Lord Halsbury.

3s [1905] A.C. 392

36 (1889) 14 App. Cas. 337.

${ }^{37}$ (1827) 4 Bing. 66; Betts v. Gibbins (1834) 2 Ad.\&El. 57; Toplis v. Grane (1839) 5 Bing.N.C. 636; Dugdale v. Lovering (1875) L.R. 10 C.P. 196.

38 Though there has been much discussion over the related question, whether an act done in reliance on a promise can be a good consideration if the act was not requested. But in those cases the question is whether a request is a necessary condition of enforceability of unilateral promises. In the present cases request is treated as a sufficient condition for the implication of a warranty.
} 
contracts, either, and they are ignored by the contract books as much as the tort books. There is certainly no express promise to indemnify the plaintiff, nor is there any very obvious consideration. Moreover, they cannot, (it seems) be treated as cases of genuine impliedin-fact promises, because in Dugdale v. Lovering ${ }^{39}$ (which was approved in Sheffield Corporation v. Barclay) no such implication could possibly have been made. In that case the plaintiffs had railway trucks in their possession which had been sent to them by a party who had become bankrupt. The defendant was the trustee in bankruptcy, and he demanded return of the trucks. Third parties, however, claimed that the trucks had been sold to them by the bankrupt. The plaintiffs asked the defendant for an indemnity in the event of their delivering the trucks to him and later being held liable to the third parties; the defendant refused to give any such indemnity but insisted on the trucks being handed over, whereupon the plainfiffs complied. Being later held liable to the third parties they now sued the defendant for an indemnity. The defendant was held liable although there was no express promise of indemnity and manifestly no promise could have been implied-in-fact.

If, on the other hand, these cases are to be treated as based on a promise 'implied in law' further questions spring to mind. First, a promise 'implied in law' looks very like a species of quasi-contract and indeed the request principle seems to have been treated as such by Lord Wright in Secretary of State for India v. Bank of India. ${ }^{40}$ But this approach too has difficulties: the defendant's liability in these cases is to indemnify the plaintiff against his losses and not to make restitution of any benefits or gains. The principle is not discussed at all in Goff \& Jones on Restitution.

Moreover, if the request principle depends on a promise implied in law' it should be possible to state the circumstances in which such a promise will be implied. Yet the request principle is itself stated in terms which are manifestly too wide. It cannot possibly be asserted that the mere request to another to do an act which turns out to be injurious to him is in all cases sufficient to impose a liability on the former to indemnify the latter. Literally interpreted, such a principle could be made to hold a seller liable to a buyer for leading him into a bad bargain merely because the former has made an offer to sell which the latter has accepted. In Birmingham and District Land Co. v. L.N.W. Railway Co. ${ }^{41}$ an argument which involved similar reasoning was rejected as obviously untenable. Lord Bowen explained the inapplicability of the 'request' principle merely by asserting that 'It is idle to say that in a contract for purchase and sale of land there is any request made by one person to the other.' ${ }^{2}$ But this is not very helpful. In point of fact there clearly may be a request: if the 'request' principle does not apply then it must be because that principle is too widely stated. Some additional fact is needed before the principle becomes applicable.

Another objection to a literal application of the request principle

\footnotetext{
s9 Supra.

40 [1938] 1 All E.R. 797.

4 (1886) 34 Ch.D. 261.

1d Id. at 275 .
} 
is that it would convert many credit-references into contracts of suretyship. A person to whom application is made for a reference may in a sense request the third party to deal with the applicant but such a request is not the same as a promise to be answerable in the event of default. It imposes no doubt a duty of honesty ${ }^{43}$ and even of care ${ }^{44}$ but it is plainly not a warranty. ${ }^{45}$

It is clear, then, that there is something missing in the traditional formulations of the request principle. My submission is that the missing element is a reference to misrepresentation. It is the combination of misrepresentation coupled with a request that the promisee should act on the representation which often justifies the Courts in treating the representation as a warranty. I believe that in all the cases in which the request principle has been applied there will be found some element of express or implied misrepresentation and that the resultant liability to indemnify the plaintiff can be most intelligibly explained as a liability for breach of warranty.

It is true that in Sheffield Corporation v. Barclay the House of Lords appeared to think that the 'request' principle was quite independent of any misrepresentation by the defendants. But it is nevertheless clear that the liability they imposed was conceived to be a contractual liability and Collen v. Wright was cited by Lord Davey to show that the plaintiffs' action in reliance on the representation could be treated as consideration. It is significant that Lord Davey also said that he thought the defendants had affirmed and warranted the genuineness of the forged transfer. Oddly, Lord Davey adds that it was unnecessary to decide if there was any such warranty; yet the decision seems necessarily to involve that there was a warranty.

I will return later to the 'request' principle because I believe that it sheds light on a number of important policy questions about liability for misrepresentations generally. But for the moment I return to the question of consideration as a requirement where the misrepresentation has not induced a contract between representor and representee.

\section{c. Consideration and misrepresentation}

We have seen how in Collen v. Wright no difficulty was found in treating the plaintiff's conduct in entering into the transaction as a sufficient consideration to support an action on the agent's representation of authority as a warranty. In Starkey v. Bank of England no mention was made of the question of consideration from beginning to end of the case, and in the Sheffield Corporation case, only Lord Davey felt it to be necessary to affirm that the act of the Corporation in registering the transfer was a sufficient consideration.

It will be seen that the willingness of the Courts to treat such conduct as a sufficient consideration meant that henceforth the consideration problem was largely disposed of. So long as the plaintiff has acted to his detriment in reliance on a representation it is possible to find a consideration, at least where the action was expected or foreseeable by the representor. The fact that action in reliance plays the same role

\footnotetext{
${ }^{43}$ Pasley v. Freeman, supra.

“ W. B. Anderson \& Son L\&d. v. Rhodes [1967] 2 All E.R. 850.

is Haycraft v. Creasy (1801) 2 East. 92.
} 
when treated as a ground for relief for misrepresentation and as consideration is well illustrated by Australasian Brokerage Ltd. v. A.N.Z. Banking Corporation ${ }^{46}$. It was here held that a fraudulent representation by one contracting party to another which induces the latter to perform his contract is not actionable in deceit. This is, of course, merely an application to the tort of deceit of the familiar rule that performance of an existing duty may not be a good consideration.

In the great majority of cases it is precisely the element of reliance that gives rise to the representee's loss and leads to claims for relief for misrepresentation. But as we have already mentioned, it is possible though less common for representations to give rise to expectations just as promises do. At present an 'unacted upon' representation standing alone resembles a gratuitous promise. Both may give rise to expectations which are not legally enforceable. The question may then be raised whether a representation of this character should be enforceable even if not acted upon. The nature of the question may be illustrated by considering certain types of representation which at present are usually enforced by way of estoppel. For example, A steals a share certificate and forges a transfer in the owner's name. B buys the shares in good faith and is registered by the company who issue him with a new share certificate. This certificate is a representation that $B$ is the owner of the shares. It may well give rise to "expectations' in B's mind, e.g. that he will receive dividends. But unless and until he acts to his detriment upon the representation he will have no relief against the company. ${ }^{47}$

It does not seem at all obvious that the law is unreasonable in refusing relief for unacted upon misrepresentations. It is precisely in this type of situation that the differences between promises and representations seem most significant. The representor has received no benefit from his representation, has not intended to undertake any commitment and is just as innocent as the representee. And the representee's only complaint is that he has been disappointed in the expectations which the representor has raised in him.

\section{d. The policy issues}

Apart from doctrinal difficulties, it is important to enquire whether there are significant policy issues wrapped up in the distinction between the representation which induces a contract between the parties and the representation which does not. Given that the consideration difficulty can be overcome, is there any reason why the Courts should be more willing to find an 'intent to warrant' in the case of a representation which leads to a contract between the parties than a representation which is relied on by the representee so as to cause him loss in some other way?

There seems no doubt that representations will much more readily be treated as warranties in the former case than in the latter case. Certainly in contracts of sale of goods we are not today in practice very far removed from the American position whereby an affirmation by the seller is always treated as a warranty. That there may be situa-

${ }^{46}$ (1934) 52 C.L.R. 430.

${ }^{47}$ Simm v. Anglo-American Telegraph Co. (1879) 5 Q.B.D. 188. 
tions in which justice is better served by denying strict liability for representations, even between contracting parties, is shown by the well-known case of Oscar-Chess v. Williams ${ }^{48}$ but there is no question that this was an unusual case involving special features, not the least of which was that the buyer was the dealer with presumptively greater knowledge and the seller was the private consumer. Perhaps we have now also arrived at the stage where a representation by a dealer as to the quality of goods will normally be treated as a warranty even if the representee buys the goods from a third party rather than the representor; these are the familiar 'collateral contract' cases.

But when we consider other types of representation leading to conduct in reliance, the general approach of English lawyers is still to categorize the case as a tortious one, and then the 'general principle' that no damages can be awarded for innocent misrepresentation is sure to be advanced. Why is this so? What, in terms of policy, distinguishes (1) the ordinary representation leading to contract which is called a warranty, and (2) a representation not leading to contract between the parties which is also treated as a warranty, and (3) other representations which are not treated as warranties?

I suggest that the answer is largely to be found in a number of policy factors. First, a representation is more likely to be treated as a warranty where the representor derives some benefit from the action which is taken by the representee in reliance on the representation. Secondly, the representation is more likely to be treated as a warranty if the Court thinks that as between the parties the primary responsibility for ascertaining the facts rests on the representor rather than the representee. A third more complex factor (I suggest below) concerns the relationship between misrepresentations and the rules relating to the transfer of property in string transactions.

\section{i. Benefit}

It is perhaps not surprising that the element of benefit to the representor should be a material factor in these cases. Where there is some element of benefit the whole transaction begins to approximate more closely to the ordinary bargain; detriment to promisee and benefit to promisor are, of course, the hall marks of the typical bilateral contract. I do not, of course, suggest that 'benefit' has a technical meaning here, or that its presence can be tested by study of the cases on consideration. But what I do suggest is that this is one of the factors which lead lawyers to classify such cases as 'warranty' or contractual situations and therefore to impose stricter duties on the representor. ${ }^{49}$

Where the representation induces a contract between the parties to the representation the element of benefit is obviously present. In the ordinary contract of sale of goods the buyer pays more for goods represented to have certain qualities; if the goods do not have these qualities, therefore, the buyer has not only acted to his loss but the seller has been unjustly enriched. He has received more than the goods are worth. And this result remains the same even if the representa-

\footnotetext{
4" [1957] 1 W.L.R. 370.

4 For this reason I cannot agree with the views of Fullagar J. in (1951) 25 A.L.J. 278, 283, that the implied warranty of authority cases are 'altogether anomalous'.
} 
tion was wholly innocent. This is, therefore, the strongest case for giving the representee a remedy by way of warranty..$^{50}$

Where the representee's conduct in reliance takes a different form, there may or may not be any element of benefit to the representor. The implied warranty of authority cases are perhaps borderline in this respect, but certainly, in many such cases the agent would derive a direct or indirect benefit from the contract. In many other cases classified as collateral contracts there will also be some indirect benefit to the representor, as in the typical hire-purchase situation where the dealer misrepresents the condition of the goods and induces the representee to acquire them on hire-purchase. Although the representee does not contract with the representor the latter will benefit from the representee's actions. The goods must be sold by the dealer to the finance company in order to be supplied to the hirer. On the other hand there are cases in which the representor gives a wholly disinterested reference about the credit or standing of another. In essence this was the situation in Pasley v. Freeman and in the Hedley Byrne case; in both cases A made a representation to $B$ as a result of which $B$ entered into a contract with $C$. The basic facts in these cases seem identical with those in many of the collateral contract cases, and yet the legal result is entirely different: the difference seems to lie largely in this element of benefit. ${ }^{51}$

At this point I return to the request principle. In the light of the suggestion made above about the importance of the element of benefit to the representor, it becomes clearer why a 'request' is regarded as so significant. A 'request' to another to act in a certain way is, on the face of it, good evidence that the requestor expects to derive some benefit from the act to be performed. This very argument was relied upon in Bank of England v. Cutler ${ }^{52}$ where the facts were somewhat similar to those in Starkey v. Bank of England. But in the Cutler case the defendant broker did not put forward any forged power of attorney; he personally attended at the Bank's premises and identified one J.P. as M.P., the owner of some stock. The broker acted in complete good faith but was nevertheless held liable by a majority of the Court of Appeal on the principle of Sheffield Corporation v. Barclay. Counsel for the broker protested that the whole case was in effect an action for damages for misrepresentation, and he went on:

If every statement upon which it is intended that another shall act is to be treated as involving a request to him to act, then there is really an end of the principle affirmed in Derry v. Peek. ${ }^{53}$

This argument was accepted by Vaughan Williams, L.J. who dissented and who thought that the broker had acted more as a witness than as a moving party.

There must, he said, be a request, and the request or invitation must be under such circumstances that one can as a matter of law imply the intention to warrant;

\footnotetext{
si) Perhaps this is only so where the seller is selling in the course of business, or where the goods are new. I doubt if the same arguments hold good for the sale of houses. In such transactions the discovery of defects, etc. which have been innocently misrepresented not to exist, seems more analogous to the occurrence of a new loss, the risk of which falls on the buyer.

31 This probably also explains why in Low v. Bouverie, supra, the Court found no 'intention' to contract and no consideration although here again the representee had acted on the representation in a foreseeable way.

s2 [1908] 2 K.B. 208. Cf. Gowers v. Lloyds \& N.P.F. Bank [1938] 1 All E.R. 766 where bankers were held not liable for wrongly certifying a customer to be alive as a result of which plaintiffs continued to pay his pension.

ss Id. at 215.
} 
and generally speaking, such intention will not be inferred except in cases where the request or invitation is made by some one who will derive a benefit from com. pliance with the request. . $^{54}$

The majority of the Court, however, found a sufficient 'request' though the difference of opinion seems to have been on the interpretation of the facts rather than the law. Vaughan Williams, L.J. seems to have thought that the broker had attended at the Bank as a disinterested witness; the majority thought, more realistically, that the broker had attended in the ordinary course of his business as a broker. On this view, he plainly expected to derive some benefit, however indirect, from his 'request'.

But although benefit is thus often an important factor, I do not think it can be said that a representation can never be treated as a warranty where there is no benefit to the representor. Where the representor knows that the representee is going to commit himself in some serious step in reliance on the representation justice may require the representation to be treated as a warranty apart from any element of benefit. 55

\section{ii. Responsibility}

The second principal factor concerns the relative position of the parties with regard to the facts represented. One important element in this is the means of knowledge. We have seen how in Collen v. Wright the Court thought that an agent ought to know the extent of his own authority. Where the parties have equal means of ascertaining the facts the traditional individualism of the common law led to a disinclination to give relief to the representee; he should have looked to the facts himself and not trusted to the representor. This line of thought is often to be found in the cases distinguishing between 'statements of fact' and 'statements of opinion', but it also has a bearing on the possibility of treating a representation as a warranty. There are even some cases in which an agent (of sorts) may not know much about his principal. In Dickson v. Reuter's Telegraph Co., ${ }^{56}$ for instance, the Court of Appeal held that the defendants did not warrant that a telegram delivered by them was in fact dispatched by the person represented. It was pointed out that the defendants were mere messengers who did not necessarily know anything about the identity of a person sending a telegram.

But means of knowledge is not the only factor involved here. There are many cases in which it is evident that the Courts have had decided views as to who had the primary responsibility for ascertaining the facts. This appears, for instance, in cases like Sheffield Corporation v. Barclay where there was'much argument over the Corporations's responsibility to maintain a register of stock. Where the dispute has been between a corporation and a purchaser of shares or stock who has relied on a (false) certificate issued by the company, the Courts have laid stress on the fact that it is the company's responsibility to maintain a correct share register. ${ }^{57}$ Where, however, as in Sheffield

\footnotetext{
34 Id. at 219.

5s See, e.g. Maunsell v. Hedges (1854) 4 H.L.Cas. 1039 where Lord Cranworth says that a declaration by A to $B$ that he has executed a deed undertaking to leave property to $B$ will become a binding contract if $B$ acts upon it by getting married, assuming $A$ to have known of $B^{\prime} s$ intention.

36 (1877) 3 C.P.D. 1.

57 In Re Bahia and San Fransisco Rail Co. (1868) L.R. 3 Q.B. 584.
} 
Corporation v. Barclay, the dispute has been between a party who has in good faith submitted a false or forged transfer and the corporation itself, the Courts at first found more difficulty. On the one hand, they evidently felt that it still remained in a sense the responsibility of the corporation to keep a proper register; ${ }^{58}$ and arguments have been based on the fact that corporations can and do make inquiries of the registered holder before registering a transfer..$^{59}$ On the other hand, it was felt that in practice corporations must often rely on the accuracy or validity of transfers submitted for registration when accompanied by proper certificates. In Sheffield Corporation v. Barclay the House of Lords went so far as to say that the act of the Corporation in registering transfers was 'ministerial' and this notion was incorporated in the request principle as there formulated. It seems plain that use of this word was merely intended to indicate that, as between the corporation and the party submitting the transfer, the corporation's role was a passive one, and did not place upon them the responsibility of ascertaining the validity of the transfer. ${ }^{60}$ But it is also clear that, as between a representor and a representee, the primary responsiblity may be on the former even though the latter is not acting 'ministerially' and later cases have shown that this is not a necessary requirement of warranty.61 These cases show that it does not always matter that the representee has not acted 'ministerially', for example, where the representor was legally entitled to call on the representee to act in a certain way on the basis of certain facts being shown. Where this is the case there is a strong ground for saying that prima facie the responsibility for ascertaining the truth of the facts is on the representor. So, for instance, where a common carrier was required to carry goods, the court was even willing to imply a representation that the goods were safe and then hold this to be a warranty. ${ }^{62}$ Similarly, where the master of a ship was required by a charterparty to sign bills of lading presented to him by the charterers, the primary responsibility for seeing that the bills were in accordance with the terms of the charterparty was held to be on the charterer and he was treated as both representing and warranting that this was so.63

\section{iii. Representations and the transfer of property in string sales}

In determining, who, as between representor and representee, should be regarded as primarily responsible for ascertaining the truth, it is possible that the Courts have been influenced by another policy consideration. In many of the actual cases the representation has been wholly innocent and the loss has been caused by some fraudulent

se See Simm v. Anglo-American Telegraph Co. (1879) 5 Q.B.D. 188, 195 where Lindley J. said it was the company's duty 'to look to their own register'. This was overruled in the Sheffield Corporation case.

59 In Bank of England v. Cutler, supra, it was in evidence that the Bank only did this for transfers exceeding $\mathfrak{£ , 0 0 0}$ in view of the very large numbers of transfers of smaller amounts.

60 It is interesting to compare the position in regard to registered land. Originally the principle of Sheffield Corporation v. Barclay was applied as between a party submitting an invalid application for registration and the Land Registry (Attorney-General v. Odell [1906] $2 \mathrm{Ch}$. 47). But the policy behind land registration clearly differed from that behind stock registration: the Land Registry was intended to have the responsibility of thoroughly checking titles, etc. before registering them, and registration was intended to give a guarantee of validity. Accordingly the Odell case was reversed by 8.83(4) of the Land Registration Act 1925. It has however, been suggested that the practical effect of the case has been unwittingly restored by the Land Registration Act 1966, see Cretney \& Dworkin, Rectification and Indemnity: Illusion and Reality, (1968) 84 L.Q.R. 528.

s1 See, e.g., Banfield v. Goole Transport Ltd. [1910] 2 K.B. 94.

62 Bamfield v. Goole Transport Ltd., supra.

63 Kruger \& Co. Ltd. v. Moel Tryvon Ship Co. Ltd. [1907] A.C. 272. It was expressly denied that the master's role was purely 'ministerial'-he could have refused to sign; at 282 . Dawson Line Ltd. v. Aktiengesellschaft Adler [1932] 1 K.B. 433. 
party. It is noticeable that, whether by accident or design, the decisions nearly always place the responsibility on the party nearest in the chain to the fraudulent person. In this respect the law relating to the implied conditions as to title in the Sale of Goods Act, the cases of estoppel by representation in share and stock certificates and many other cases seem to produce a similar result. Thus if a thief steals goods and sells to $A$ who sells to $B$ who resells to $C$, the loss at common law is nearly always pushed back up the line to $\mathrm{A}$. $\mathrm{He}$, of course, may have a legal remedy against the thief though one which is unlikely to be of much use.

The same seems to be true of other dealings in goods which involve successive conversions. For example in Grace Bros. Ltd. v. Lawson ${ }^{64}$ furniture storers were induced by the fraud of a third party to send the goods to auctioneers for sale. The owner recovered damages against the storers who attempted to recover in turn from the auctioneers. The action failed as the plaintiffs had represented to the auctioneers that they had the owner's authority to send the goods for sale; in fact if the owner had sued the auctioneers they could probably have secured an indemnity from the plaintiffs. Similarly in the share certificate cases there is usually an initial fraudulent party who steals a share certificate and forges a transfer. Again the effect of the cases is generally to pass the liability along the chain until it reaches the person who actually dealt with the fraudulent party. But fraud is not always involved. For instance if A 'requests' B to do something which causes loss as a result of the negligence of $\mathrm{X}$, there is a tendency to give $\mathrm{B}$ a right of indemnity from $\mathrm{A}$, where $\mathrm{A}$ can in turn claim against $\mathrm{X}$ but B cannot. ${ }^{65}$

This general policy seems to have been influenced by two obvious considerations. First, if there is any chance of recovery from the original fraudulent party, the loss must be passed along the chain, for there would normally be no prospect of a successful action being brought against the original defrauder by a person lower down the chain. ${ }^{66}$ And secondly, if there is no prospect of recovery from the fraudulent party, the person who dealt directly with him should be left to bear the loss since it was he who in a sense 'started it all' by trusting the defrauder.

The first argument is inapplicable where the last person in the chain has a remedy himself against the fraudulent party, e.g. where he has had direct dealings with him. In such circumstances there is no need to pass the liability up the line. And the second argument is also less forceful where the last person has had direct dealings with the fraudulent party, because he is then not in such a good position to accuse the first party of 'starting it all' by trusting the fraudulent party. Accordingly (it seems) in such a case there is less chance of a representation being held to be a warranty. The point is best illustrated by Guaranty Trust Co. v. Hannay ${ }^{67}$ where it was held that the purchaser of a bill of exchange with shipping documents attached, who presents it for acceptance and receives payment, is not liable to

64 (1922) 31 C.L.R. 130.

os See Groves \& Sons v. Webb \& Kenward (1916) 85 L.J.K.B. 1533.

64 The point was specifically taken in Groves \& Sons v. Webb \& Kenward, supra.

${ }^{87}[1918] 2$ K.B. 623. 
indemnify the acceptor when it later transpires that the shipping documents included a forged bill of lading. At first sight these facts resemble those in Sheffield Corporation v.Barclay, and it was argued that the defendants had represented the bill of lading to be genuine and requested the plaintiff to act upon that representation by accepting the bill of exchange. In a factual sense this argument is hard to refute; moreover there was plainly a benefit to the representor in the act which he requested the representee to perform. Nevertheless it was held that the defendants were not liable on the ground that there was no 'request' in the relevant sense. The decision is perhaps more easily understandable if it is appreciated that the plaintiffs as the acceptors of the bill of exchange could have sued the fraudulent parties who originally drew the bill and attached to it the forged bill of lading. Stripped to their simplest, the facts in the Guaranty Trust case really came down to this: that $X$ had obtained money from $A$ by fraud and that, by arrangement with $\mathrm{X}$, this money was later paid off from other moneys supplied by B. Although A had passed on to B the misrepresentations of $\mathrm{X}, \mathrm{A}$ was himself acting in good faith and he received the money from $B$ in discharge of a liability due to him. Moreover X was clearly liable to B.

A case very similar to the Guaranty Trust case in its essentials is the Australian case of Porter v. Latec Finance (Qld.) Pty. Ltd ${ }^{68}$ although the issue in this case became totally obscured as the judgments became entangled with problems of mistake of identity in contract. In this case one $G$ forged a mortgage deed and borrowed $£ 1,500$ from the defendant on the security of this mortgage; later $G$ wanted to borrow more and he therefore forged a new mortgage in favour of the plaintiffs, this time for $£ 3,000$. The defendant's loan was paid off out of the $£ 3,000$ lent by the plaintiffs. When the fraud was discovered the plaintiffs sought to recover the $£ 1,500$ from the defendant. Since the defendant had surrendered the certificate of title to the plaintiff's solicitors on payment of his loan, it could have been contended that the case fell within the Sheffield Corporation principle; the defendant might be said to have represented that the certificate was validly charged with a mortgage. But here again it will be seen that essentially what had happened was that a rogue had incurred a liability to $\mathbf{A}$, and had then defrauded $B$ and paid off $A$ out of the proceeds. Here again, therefore, the policy of the Courts seems to be to protect $A$ rather than $B$. In these circumstances $B$ can sue the fraudulent party directly, and if this action is fruitless, the loss lies on B. In these cases the original fraudulent party has in a very real sense defrauded both victims, one in succession to the other, and the role of the first victim in regard to the second victim is much more passive. In the case of string sales of goods etc., the original fraud may be said to end with the first sale; and thereafter it is the first victim who (though unwittingly) helps to defraud the second.

\section{Estoppel by Representation \\ 1. Introductory}

It is well known among lawyers that a representation which cannot be directly sued on in contract or tort may nevertheless be actionable 
with the assistance of the doctrine of estoppel by representation. But there are a number of very puzzling features about this form of estoppel. The constant assertions that estoppel is not 'a cause of action in itself' and that it is a rule of evidence rather than a rule of law make it very difficult to understand the role of estoppel and its relationship to the rest of the law relating to misrepresentation. How does estoppel fit in with liability for breach of warranty and liability in deceit and in negligence? Is this a form of 'strict liability' analogous to liability on a warranty, or is it more analogous to liability for fraud or negligence? What is the significance of the assertion' that estoppel is not 'a cause of action'? Is it really a rule of evidence? And more fundamentally, do we need a doctrine of estoppel by representation in a sensible Contract Code? Before I look into these questions, it may be useful to list a number of typical situations in which the Courts have in fact used estoppel by representation to enable damages to be awarded.

$i$. Share certficates: ${ }^{69}$ It is now well established law that a company which issues a share certificate stating that $\mathrm{X}$ is the owner of certain shares is estopped from denying this fact to a purchaser of the shares who has bought in reliance on the certificate. If $X$ was not in fact the owner, the company cannot register the buyer as the owner of those shares for this would infringe the rights of the true owner; but the company is bound to register the buyer as owner of other shares of the same issue, or, if it cannot, it will have to pay him damages.

ii. Bills of lading: ${ }^{70}$ If a shipping company issues a bill of lading which falsely states that the goods were shipped "in apparent good order and condition" the company will be estopped from denying that they were so shipped when sued by an endorsee of the bill of lading.

iii. Warehouse keepers, ${ }^{71}$ etc.: A warehouse keeper who issues a warrant or certificate stating that he has certain goods in his possession is estopped from denying this fact if sued by someone who has bought the goods in reliance on such a warrant or certificate.

iv. Trustees, ${ }^{72}$ etc.: A trustee who, in answer to enquiry by one considering lending money on the security of an assignment of a beneficial interest in a trust, declares that there are no prior charges on the interest, will be estopped from denying this against the party acting upon that representation.

\section{Estoppel not a cause of action in itself?}

I wish to start by examining the frequent assertion that 'estoppel is not a cause of action in itself. This is a rather strange phrase particularly when combined with the assertion that estoppel is a rule of evidence. If estoppel is indeed a rule of evidence then it would obviously follow that it could not itself be a cause of action. Whatever the precise meaning of 'cause of action' it is scarcely possible for a rule of evidence ever to be such a thing. It seems that the denial that estoppel can be a cause of action in itself is really intended as a

\footnotetext{
69 Re Bahia \& San Francisco Railway Co., supra; Balkis Consolidated Co. v. Tomkinson [1893] A.C. 396.

io Compania Naviera v. Churchill \& Sim [1906] 1 K.B. 237; Brandt v. Liverpool etc. Steam Navigation Co. [1924] 1 K.B. 416.

"Seton, Laing \& Co. v. Lafone (1887) 19 Q.B.D. 68.

'2 Burrowes v. Lock (1805) 10 Ves. 470; Low v. Bouverie [1891] 3 Ch. 82.
} 
denial that the representation which founds an estoppel can itself be a cause of action. This assertion is commonly explained by insisting that the plaintiff must have an 'independent cause of action' and cannot rely on the representation alone. Thus in the share certificate cases the plaintiff's cause of action is said to be, not the misrepresentation in the share certificate on which the plaintiff relied, but the refusal of the company to register him. Similarly in the bill of lading cases the endorsee's complaint is not that the shipping company have misrepresented the state of the goods but that they have delivered to him damaged goods when (according to their own word) they received them in good order and condition. And so on.

It is my contention that these arguments are transparently fallacious and that a few moments devoted to their consideration will show them to be without any substance. The precise meaning of the phrase 'cause of action' may be a matter of doubt, and it may in any event vary according to context. But it may safely be said that in an action for substantial damages the plaintiff must in every case prove-

1. that he has suffered damage, and

2. that the damage was the result of some facts giving rise to a ground of complaint in law.

Since the first requirement is common to all actions for substantial damages there is a tendency for lawyers to ignore it, and to fasten on the second requirement in discussing 'causes of action'. Thus we say that the plaintiff's 'cause of action' is based on the defendant's negligence or fraud or breach of contract. We do not say that the plaintiff's cause of action is for (say) 'pain and suffering' or 'loss of $£ X$ '.

Now the process by which lawyers have (it seems) convinced themselves that estoppel is not 'a cause of action in itself' can be seen to be a very simple one. The representation which is the ground of complaint is ignored and the cause of action is said to be the damage which the plaintiff has suffered. Thus in the share certificate cases the cause of action is the 'failure of the company to register the plaintiff as a shareholder'; in the bill of lading cases it is the 'delivery of damaged goods'; and so on. But it is surely clear that these cannot themselves be treated as causes of action; they are statements of the damage the plaintiff has suffered, not the ground of his complaint in law. The damage in such cases no more amounts to the cause of action than 'pain and suffering' could be a cause of action in a personal injury claim. And the reason is surely plain. The damage when considered alone gives no indication that it has been inflicted in circumstances giving rise to a legal remedy. If a company refuses to register the plaintiff as a shareholder this cannot by itself be a cause of action because there is nothing so far to indicate that the refusal was wrongful, or that the plaintiff was entitled to be registered. And it is impossible to explain why this should be wrongful without explaining that the company has by its misrepresentation led the plaintiff to believe that he would be entitled to be registered, and that he acted on that belief by buying the shares. Similarly with the bill of lading cases. The delivery of damaged goods is not in itself wrongful; it is only wrongful because the shipping company has misled the endorsee of the bill of lading into taking up the bill in the belief that the goods are not damaged. 
I submit, therefore, that it is perfectly plain that the cause of action in a case of estoppel by representation is in fact the representation, and that what is conventionally stated to be the cause of action is merely the damage. The belief that estoppel is not a cause of action in itself is a myth.

It does not, however, follow that every case of estoppel by representation resembles an action for damages for misrepresentation. There are undoubtedly some peculiar features about estoppel by misrepresentation which have (I believe) prevented its true nature from being more clearly observed. In particular it has often been insisted ${ }^{73}$ that a person who relies on estoppel by representation is not complaining of misrepresentation. He is not, as he would be in an action of deceit, suing on the basis that the representation is false, but on the basis that it is true. How then can it be asserted that the plaintiff's cause of action is the misrepresentation? I believe that the answer to this objection is as follows. Representations, like promises, may give rise to different remedies. When a promise is broken the promisee may be able to choose between (1) affirming the contract and treating it as still in force even to the extent of suing for specific performance, or (2) accepting the breach, treating the promise as no longer binding, and suing for damages. Equally, it seems to me that the law may offer different remedies to a representee for misrepresentation (although they may not always both be available, any more than in the case of promises). It may offer him the remedy of (1) 'affirming' the representation, i.e. treating it as true, and claiming whatever relief would be appropriate if it were true; or (2) accepting that the representation is untrue, and suing for damages accordingly.

Basically my submission is that estoppel by misrepresentation is the first of these two alternatives; it is thus a remedy for misrepresentation which corresponds in some respects with the remedy of specific performance for breach of promise. It corresponds with that remedy in that the innocent party is in both cases entitled to hold the other party to his word. A party who is estopped from denying the truth of the facts he has represented is in a similar position to a promisor who has broken his promise, but who is sued for specific performance; he too 'cannot deny' the continued subsistence of his duty to perform the promise. And just as the promisee cannot both accept the repudiation of the contract and hold the contract to be still in existence, so too a representee cannot both insist on the truth and rely on the misrepresentation at the same time. ${ }^{74}$

It now also becomes clear what is meant by the assertion that there must be 'an independent cause of action' if an estoppel is to be set up. Plainly if the representee chooses to 'affirm' the truth of the representation and claim such relief as would be appropriate if the representation were true, he must in fact be able to show that there is some such relief available. In all the four types of cases listed at the beginning of this section there would be such relief. In the share certificate cases, the representee would be entitled to be registered

\footnotetext{
${ }^{73}$ See Low v. Bouverie [1891] 3 Ch. 82, per Kay L.J. at 112.

7 See Scarf v. Jardine (1882) 7 App.Cas. 345 where it was said that a party cannot rely on the truth and an estoppel at the same time. However, the decision itself seems to have been an unnecessary application of the principle.
} 
as a shareholder if the representation were true; in the bill of lading cases, the representee would be entitled to have undamaged goods delivered to him; in the warehouse keeper cases the representee would be entitled to have the goods delivered to him; and in the trustee cases, the representee would be entitled to the charge on the trust fund of which he has given notice. All this does not mean that the misrepresentation is still not an essential part of the cause of action. The representee is entitled to treat the representation as true; and if it were true he would have an 'independent cause of action'. But if there had never been any representation at all the 'independent cause of action' would never have arisen. The word 'independent' is thus somewhat misleading. The position is almost precisely analogous to a suit for specific performance. Specific performance is not itself a cause of action'; a suit for specific performance must be supported by an 'independent cause of action'; viz. a right of action on a contract. But this does not mean that specific performance is quite independent of the promise which has been broken and which it is sought to enforce. If there had been no promise there would have been no contract; and without contract there would be nothing to enforce specifically.

But it must be stressed that all this is only the case where the representee claims to rely on the truth of the representation. If he takes the alternative course of 'repudiating' the representation, then no question of estoppel arises at all, and the only question is whether the misrepresentation itself is actionable as a warranty or for fraud or negligence.

Why has this myth that 'estoppel is not a cause of action' grown up? The reason is not far to seek. It grew up as a direct result of the decision in Derry v. Peek. ${ }^{75}$ When the House of Lords affirmed that there was a general principle that no damages could be awarded for innocent misrepresentation a great deal of current law was immediately thrown into doubt. This is not the place to attempt a full survey of the nineteenth century cases at law and in equity in which by some means or another liability had been imposed for innocent misrepresentation; but it is an undoubted fact that there were a large number of such cases, though this has gradually been forgotten as generations of lawyers have grown up to whom Derry v. Peek was the starting point in the law of misrepresentation, rather than an unexpected check to a general current of authority. I do not suggest that prior to Derry v. Peek all misrepresentations were actionable at law or in equity, any more than all promises were actionable. But certainly where the justice of the case required it, relief had been regularly given for misrepresentation either by way of damages or by giving the representee the right to treat the representation as true. In Low v.Bouverie, ${ }^{76}$ only two years after Derry v. Peek, the Court of Appeal was at pains to insist that that case in no way affected the law of estoppel by representation. It is quite true that even before Derry v. Peek the Courts had sometimes denied that estoppel could constitute a cause of action in itself ${ }^{77}$ but this did not mean that the remedy of estoppel was not founded to some degree on the representation; it merely meant that if the representee

75 (1889) 14 App. Cas. 337.

76 [1891] 3 Ch. 82.

7) See Seton, Laing \& Co. v. Lafone (1887) 19 Q.B.D. 68 at 70. 
affirmed the truth of the representation he had to have some right to relief as a result of that affirmation. After Derry v. Peek the Courts seized on the idea that estoppel was not a cause of action as one way of distinguishing that decision.

\section{A rule of evidence or a rule of law?}

It is now possible to understand why the idea of estoppel as a rule of evidence has proved so tenacious. The party estopped 'cannot deny' or 'cannot be allowed to dispute' the truth of the facts he originally asserted; this way of formulating the rule gives way easily enough to a formulation in terms of evidence 'the party estopped cannot produce evidence to deny' the truth of the facts asserted. ${ }^{78}$ But, in my submission it is quite plain that estoppel is no more a rule of evidence than a so-called 'irrebuttable presumption'. Most lawyers are well aware that such a 'presumption' is a rule of law masquerading as a rule of evidence, and the same seems to be the case with a "conclusive admission". The modern tendency-propounded in Cross on Evidence 79 and now adopted in Spencer-Bower on Estoppe ${ }^{80}$-is still to insist that estoppel is a rule of evidence, but to admit that like other rules of evidence it may have the practical effect of creating substantive rights. No doubt this argument is somewhat academic but I do not believe any real progress can be made in reforming (and above all simplifying) the law until the true nature of estoppel is fully appreciated. And I find it necessary to refuse to embrace even this compromise. The true position, I submit, is as follows. When a party is estopped from denying the truth of his representation he is not entitled to deny those representations, and the representee is entitled to certain relief as if the facts represented were true. If evidence were admitted which showed that the facts represented were untrue it would be irrelevant; the rights and liabilities of the parties would still be determined by the facts as they were represented to be and not by the facts as they actually are. To ask whether in such circumstances the relevant rule is a rule of law or a rule of evidence is to some extent like asking whether the chicken or the egg came first. Clearly it is possible to argue that, (1) the parties' rights are regulated by the facts as represented rather than the actual facts because no evidence of the actual facts can be given; or (2) that no evidence of the actual facts can be given because such evidence would not affect the rights of the parties which are anyhow regulated by the represented facts. In this situation there is surely only one way of deciding which is correct; 81 namely to ask whether the exclusion of the evidence is based on grounds which are in any way related to the general purposes of the law of evidence, viz., proof of relevant facts by satisfactory means. The answer is surely No. The evidence is not excluded because of possible un-

\footnotetext{
78 It is, however much more difficult to apply formulations like this to estoppel based on promises, see Henderson, Promissory Estoppel and Traditional Contract Doctrine, (1969) 78 Yale L.J. 343, 376-377. (I have elsewhere suggested that there is no need for promissory estoppel to be recognised as a form of estoppel at all, but current doctrine does recognise it.)

79 3rd ed., at $289 \cdot 290$.

Bo 2nd ed. (1966) at 7-8.

st An alternative approach might be to ask which rule came first historically. It is possible that exclusionary rules of evidence may at one time have been introduced and that these rules may have gradually led to rules of substantive law which would then have kept out the evidence as irrelevant. But I do not believe this was the course of development in estoppel by representation. For one thing (as Ewart pointed out long ago, Estoppel by Misrepresentation (1900) at 189 et seq.) the evidence is nearly always admitted in practice in cases of estoppel by misrepresentation.
} 
reliability or any other evidentiary principle. It is excluded because it would be unjust to admit it and allow the rights of the representee to be affected by it. ${ }^{82}$ Therefore it seems more correct to say that the evidence is excluded because of the rules of substantive law which make the evidence irrelevant.

But although the true nature of estoppel by representation is now seen to be a remedy in the nature of specific performance, there are still a number of peculiar features about the doctrine which require further consideration. First, what is the practical effect of estoppel? Secondly, what is the relationship between this remedy and other remedies for misrepresentation? Thirdly, why is it that this remedy seems to be more readily available than the remedy of damages, in contrast to the position regarding promises which is, of course, quite the reverse?

\section{Practical effects of estoppel}

The first question which arises here is how does it come about that the effect of estoppel is so often to give damages to the representee if, as I have suggested, estoppel is a remedy corresponding in some sense to specific performance? The answer to this is simply that in many cases of misrepresentation the plaintiff's ultimate claim will be for damages whether he claims for relief on the basis that the representation was true or not. For example in the share certificate cases the plaintiff might claim relief on the basis that the representation was false, in which case he would acknowledge that he had no right to be registered as the owner of the shares but would (if the law allowed him to) claim damages for the loss he suffered as a result of the misrepresentation. Alternatively he can claim relief on the basis that the representation is true; on this footing he is entitled to be registered as a shareholder, and if the company does not register him, he again recovers damages. Thus in this sort of case the plaintiff's remedy is the same, whether he chooses to 'affirm' the representation or to 'accept' the fact that it was false.

But this is not always so. There are many cases in which the representee can set up the representation as a defence to an action against him if he chooses to affirm the truth of the representation; whereas if he claimed relief on the ground of the falsity of the representation his remedy would be a counter-claim of some sort. A good example is to be found in Greenwood v. Martin's Bank Ltd. ${ }^{83}$ where the plaintiff was held estopped from disputing the authenticity of his signature on some cheques; in fact his signature had been forged by his wife but the plaintiff had not disclosed this fact to his bank until after his wife's death. The House of Lords held that the plaintiff owed a duty to inform the bank of the forgery when he discovered it, and therefore his silence was equivalent to a representation that the signatures were authentic. Accordingly the plaintiff was not entitled to deny the authenticity of the signature. It will be seen that in this situation the representees would clearly have had an alternative remedy, though the net result would have been the same. Instead of claiming relief on the basis of the truth of the implied representation they could pre-

82 See, e.g., the formulation by Lord Blackburn in Burkinshaw v. Nicolls (1878) 3 App.Cas. at 1026.

(1933) A.C. 51. 
sumably have acknowledged the forgery, re-credited the plaintiff's account with the amount of the cheques, and then sued the plaintiff for damages. Since the plaintiff was held to be under a duty to inform the bank of the forgery, this duty presumably arose out of the contractual relationship between the parties; breach of this duty would therefore presumably have been actionable had any damage resulted.

As I have said, it made little difference to the net result in this case whether the representee chose to treat the representation as true or as false. Even if the plaintiff had been insolvent they would still, by pursuing either alternative, have been able to set-off the amount on the cheques against the credit in the plaintiff's account. It did not even make any difference to the role of the parties; in either event the bank, through its control of the plaintiff's bank account, did not have to commence proceedings but could simply await attack by the plaintiff. The only advantage which estoppel has in this situation is that of avoiding circuity of actions. ${ }^{84} \mathrm{~A}$ defence to a claim is simpler than imposing a liability on one party which is exactly counter balanced by a corresponding right.

But we now pass to cases in which the remedy of estoppel is decidedly superior to any form of action on the representation itself. First, there are cases in which the representee is in a very real sense able to obtain 'specific performance' of the representation which may be more important to him than damages. For instance in Hopgood v. Brown ${ }^{85}$ contractors built a bungalow and garage for the plaintiff on a site adjoining their own land. In fact the garage was partly built on land owned by the contractors, the boundary never having been clearly identified. It was held that the contractors were estopped from claiming the land: they had represented the land to be the defendant's and he was entitled to treat that representation as true. The result of this was that the defendant remained in undisturbed possession of this land, though it is perhaps not clear if he could have transferred a title to the disputed area. Clearly from his point of view, this was a more satisfactory result than an action for damages for misrepresentation could have been.

The second type of case in which the superiority of estoppel as a remedy manifests itself concerns a variety of situations in which title to goods is in question. For example, A represents to B that C has A's authority to sell A's goods. Relying on this, B buys some of A's goods from $C$ who has in fact acted without authority, e.g. because he has sold below the price stipulated by $A$. Here again $B$ may have alternative remedies: (1) to acknowledge that the representation was false, that therefore he has acquired no title to the goods, and to sue $A$ for his damages; or (2) to insist that he is entitled to treat this representation as true, and that therefore he has acquired title to the goods. Clearly the second remedy is so advantageous to the representee that it is hardly surprising if the first remedy is rarely invoked and it may even be doubtful whether it is available. In recent years it has been confirmed that the representee acquires a 'real' title in this situation and

\footnotetext{
o* See Swan v. North British Australasian Co. (1863) 2 H.\&C. 175, 190 per Cockburn C.J.; London Joint Stock Bank v. Macmillan [1918] A.C. 777 at 818 per Lord Haldane.

os [1955] 1 All E.R. 550.
} 
not merely a 'metaphorical title by estoppel'. ${ }^{86}$ This seems to confirm that the rightful place of estoppel by representation is with the rules of substantive law rather than with the rules of evidence.

\section{Incidental advantages of estoppel}

I have so far been considering those advantages of estoppel by representation which are inherent in the nature of the remedy. There may, however, be other advantages which are, in a sense accidental; they are advantages which do not derive from the real nature of estoppel but from the fact that the Courts have denied its real nature. In particular, by using the doctrine of estoppel by representation the Courts have been able in many cases to give adequate remedies where the Statute of Frauds would have raised difficulties if a different basis of liability had been urged.

\section{i. Evasion of the Statute of Frauds}

The Statute of Frauds lies in the background to a very large number of 19th century cases of representation and estoppel. In Pickard v. Sears $^{87}$ which is generally regarded as the foundation case of the whole doctrine of estoppel by representation, Lord Denman specifically refers to the requirement of written evidence for contracts of sale of goods (above 110 ) as a ground for the introduction of the rule on which the Court acted. In this famous case the plaintiff was the mortgagee of some machinery which had been owned by one M. Execution was levied by creditors of $M$ and the sheriff took possession of the goods. The plaintiff knew what was going on, and explained that he was a creditor of $M$ but never disclosed his ownership of the goods nor produced his bill of sale. The sheriff sold the property to the defendants who were then sued in trover by the plaintiff. After pointing out that the plaintiff clearly had a title to the goods Lord Denman went on to say that the title could only be divested by gift or sale, of which no specific act was even surmised. He then enunciated the principle, which still forms the basis of the law todav. that the plaintiff was 'concluded from averring' his title against the defendant, and added significantly ${ }^{88}$

and the plaintiff, in this case might have parted with his interest in the property by verbal gift or sale without any of those formalities that throw technical obstacles in the way of legal evidence.

A simple modern example of a case where estoppel by representation succeeded where difficulties might have arisen under the Statute of Frauds is Hopgood v. Brown, referred to above.

I have tried to show elsewhere ${ }^{88^{a}}$ how the idea of action in reliance on a representation as a ground for estoppel was at this stage closely linked with the notion of 'part-performance' as a ground for not insisting on compliance with the Statute of Frauds; and how Jorden v. Money ${ }^{89}$ attempted to prevent the further evasions of the Statute by refusing to treat promises in the same way as representations. I have not space here to trace the full story of these nineteenth century cases; it is enough to note that evasion of the Statute of Frauds has played a large role in the development of the law of misrepresen-

\footnotetext{
${ }^{86}$ Eastern Distributors v. Goldring [1957] 2 Q.B. 600.

87 (1837) 6 Ad.\&E. 469.

${ }^{88}$ At 474.

Considration in Contracts: A Fundamental Restatement, to be published by the A.N.U. Press.

89 (1854) 5 H.L.Cas. 185.
} 
tations. The invention of the action of deceit in Pasley v. Freeman was also attributed to a desire to evade the Statute ${ }^{90}$ and the story has not stopped even now. For one result of Pasley v. Freeman was the extension of the Statute of Frauds to cover the action in deceit by the Statute of Frauds Amendment Act 1828; and in 1967 it was held that this extension did not cover the new action for negligent misrepresentation. ${ }^{91}$

\section{ii. A doubtful case; the reasonably understood construction as against the 'true construction'}

A recent case raises the possibility that there may be yet another advantage in relying on estoppel by representation as against more direct enforcement of representations by more conventional means. In Woodhouse Israel Cocoa Ltd. v. Nigerian Produce Marketing Co. $L t d{ }^{92}$ parties had made a contract for the sale of Nigerian cocoa to London buyers at a price expressed in and payable in Nigerian pounds. Fearing devaluation of sterling the buyers, by correspondence, sought and obtained from the sellers agreement to payment in sterling. After devaluation the sellers argued that the correspondence, on its true construction, merely changed the currency of payment from Nigeria to sterling pounds but did not alter the 'money of account' i.e. the buyers were required to pay sufficient sterling to produce the requisite number of Nigerian pounds. Roskill J. evidently thought that there was some force in this argument, but he held that by raising the plea of estoppel the buyers succeeded. Whatever the 'true construction' of the correspondence might be, the construction relevant on a plea of estoppel was the construction which reasonable business men in the position of the buyers would place on the seller's assurances.

If this distinction is sound then this is no doubt another advantage of estoppel. But it is submitted that it is not sound. There is no reason whatever (I submit) for thinking that the 'true construction' of a representation means something different in estoppel from what it means elsewhere. The 'true construction' of a representation is normally the construction which would reasonably be placed upon it by the party to whom it is addressed; and that is so, whether it is treated as a variation of the contract or an estoppel.

\section{Relationship between estoppel and other remedies for misrepresentation}

Before proceeding any further it may be helpful here to list the various remedies which the law provides in different cases of misrepresentation.

1. The action of deceit.

2. The action for damages for negligent misrepresentation.

3. Defence to an action for breach of contract.

4. Rescission of a contract.

5. Damages for breach of warranty.

6. Estoppel.

Now it is clear enough that the first two remedies require respectively proof of fraud and negligence; it is equally clear that re-

so See Ashlin v. White (1816) Holt, 387 at 388.

9t W. B. Anderson \& Sons Ltd. v. Rhodes [1967] 2 All E.R. 850.

92 [1970] 2 All E.R. 124. 
medies 3, 4 and 5 require no such proof. They are instances of 'strict liability'. The question which I now wish to consider is the relationship of estoppel to these other remedies. Does it require proof of fraud or negligence or is it a species of strict liability? And if it is the latter, how can it be reconciled with the principle that damages cannot be awarded for innocent misrepresentation?

These questions have been surprisingly little discussed. But it is reasonably clear on the authorities that estoppel by representation can be a form of strict liability. When the doctrine was first propounded in Pickard v. Sears in 1837 liability for negligence was scarcely thought of, and there was basically only the single choice between liability for intentional wrongs and strict liability. In Pickard v. Sears itself the Court seemed at first to confine estoppel to the former category, for the formulation of the principle in that case referred to the representor 'wilfully' causing another to believe in the existence of the facts represented. But, as is well known, this word was explained away in Freeman v. Cooke. ${ }^{93}$ What was now said to be required was an intention' that the representation should be acted upon; and even this was qualified by explaining that the appearance of intention sufficed. So long as the representee understood, as a reasonable man, that the representation was 'meant' to be acted upon, that was sufficient.

Later still this requirement became even more attenuated. In 1887 Lord Esher said that it was sufficient if 'it was reasonable as a matter of business for the plaintiff to do what he did as a result of his belief in the defendant's statement'.94 And during the present century, at least in the bill of lading cases, the Court of Appeal has indicated that no evidence is necessary to show that an endorsee of a bill of lading has acted on the statements contained in it; ${ }^{95}$ this may be presumed. ${ }^{96}$

It will be seen that what originally appeared to be a requirement closely analogous to fraud has been totally discarded. Indeed, the requirement has passed completely out of the area of 'fault' on the part of the representor, and has simply become part of the 'inducement' which must be shown by the representee. No help is obtainable therefore, from these cases as to any requirement of 'fault' in the modern law.

But there are a number of other cases towards the end of the nineteenth century in which the Courts began to analyse this question in more modern terms. In Carr v. L.N.W. Railway, ${ }^{97}$ Brett J. introduced the possibility of 'culpable negligence' as a possible ground for supporting an estoppel. But, as is pointed out very clearly in SpencerBower's classic work, ${ }^{98}$ negligence in this context does not have its modern meaning of a breach of a duty of reasonable care. It is used in the sense of 'neglect' or 'omission'; the point which Brett J. was making was that a party might be estopped by silence (culpable neglect to speak) as much as by actual misrepresentation. Thus this dictum in no

\footnotetext{
93 (1848) 2 Ex. 654. See also Jorden v. Money (1854) 5 H.L.Cas. 185 at 212.

94 Seton, Laing \& Co. v. Lafone (1887) 19 Q.B.D. 68, at 72-73.

${ }^{95}$ Silver v. Ocean S.S. Co. Ltd. [1930] I K.B. 416.

कo But the presumption is not irrebutable: The Skarp [1935] P. 134.

97 (1875) L.R. 10 C.P. 307.

gn 2nd ed. at 70 et sey.
} 
way supports the view that negligence is relevant to estoppel by representation; it does not deal with cases of positive misrepresentation at all. But the same cannot be said of Lord Esher's next discussion of this question in the Seton, Laing case. ${ }^{99}$ In this case he does quite plainly introduce the modern notion of negligence into the doctrine.

An estoppel does not in itself give a cause of action; it prevents a person from denying a certain state of facts. One ground of estoppel is where a man makes a fraudulent misrepresentation and another man acts upon it to his detriment. Another may be where a man makes a false statement negligently, though without fraud, and another person acts upon it. And there may be circumstances under which, where a misrepresentation is made without fraud and without negligence, there may be an estoppel.

The next important case is Low v. Bouverie ${ }^{100}$ which contains what is probably still the fullest judicial examination of estoppel by representation in the law reports. In this case Kay L.J. ignored the possibility of negligence and declared that estoppel could be founded on a fraudulent or an innocent statement, though he gave no indication whether fraud was ever required to found estoppel. In the first of the bill of lading cases in 1906, it was held by Channell J. that as the estoppel arose on 'a direct statement of fact which [was] incorrect', the question of negligence did not really arise. But estoppel always arises 'on a direct statement of fact' except where it is alleged to arise from silence; this, therefore, seems to imply that estoppel can always be founded on an innocent misrepresentation, except in cases of silence.

In the more modern decision of Mercantile Credit Ltd. v. Hamblin, ${ }^{101}$ it again seems to be suggested that negligence may be essential to some types of estoppel. In this case the owner of a car signed various forms in blank and left them with a dealer to see if he could raise a loan on the car; the dealer without further authority, completed the forms and sent them in to the finance company who thought they were thereby buying the car from the dealer and letting it on hire-purchase to the defendant. It was held that the defendant was not estopped because in the circumstances the plaintiffs had to show 'an ostensible authority based on negligence' and there was in fact no negligence. The discussion of the legal concepts in this case is not at all easy to follow but it is surely unsafe to take the decision as holding that negligence is always a requirement of estoppel. Perhaps the defendant was thought not to have made any representation herself but merely to have by her silence, enabled the dealer to make the representation. This certainly accords with Ewart's view ${ }^{102}$ which (though never explicitly adopted by the Courts ${ }^{103}$ ) seems sound. According to Ewart, negligence is immaterial to a case of actual misrepresentation by the representor; moreover, there can be no such thing as estoppel by negligence without misrepresentation-the foundation of all estoppels of this species is a misrepresentation. Negligence, therefore, is only relevant where the representation was made by a third party and the party alleged to be estopped by his negligence facilitated or permitted the deception to be made. Most probably the Courts have moved uncons-

9 Supra.

100 [1891] 3 Ch. 82.

111) [1965] 2 Q.B. 242.

Iur Supra, n. 81 at Ch.IX, especially the Summary at $121 \cdot 122$.

1.1. Though it seems to be supported by Dixon J. in Thompson v. Palmer (1933) 49 C.L.R. at 547. It is also similar to the rule adopted in the Restatement of Torts: $\$ 894$. 
ciously from the notion of 'neglect' to the notion of 'negligence'. There is certainly support for the view that estoppel by silence does require proof of negligence or something akin to it. For instance, if A directly represents that $B$ has authority to sell certain property to $C, A$ will be estopped from setting up any interest of his own in the property as against $C$, even though he may not have known that he had any such interest. ${ }^{104}$ But if $\mathrm{A}$ has not made any such direct representation, but has simply stood by while B dealt with the property, A will not be estopped unless he knew of his interest. ${ }^{105}$ Similarly, in other cases of estoppel by silence something is required to make the silence culpable, and that something must at least amount to negligent conduct, although there were earlier doubts whether even that was enough. ${ }^{106}$

Whatever the true position where there is silence rather than active misrepresentation, there cannot, I think, be any doubt that there are many situations in which estoppel arises even where there is no fraud or negligence. This leads to the next major question.

\section{Estoppel and warranty}

If estoppel by misrepresentation can arise without fraud or negligence, it begins to look as though estoppel by misrepresentation is closely analogous to warranty liability. Certainly the relationship between estoppel and warranty requires further consideration. A number of basic similarities, and two obvious distinctions between these two legal concepts need to be noted.

\section{i. Warranty and Estoppel: basic similarities}

Estoppel and warranty-liability have a large number of features in common.

1. Both depend on a representation of fact. ${ }^{107}$

2. In both cases the representation must be acted upon.

3 . In both cases the representor must have intended or at least foreseen as reasonably probable that the representee would act upon the representation.

4. In both cases the legal result is independent of fraud or negligence.

5. In both cases the representee, where he can claim damages, is entitled to the contractual measure of damages, and not the tortious measure.

The first four points are clear enough and need no elaboration. The fifth is one I have not so far touched upon. It is clear law that a representee who sues for breach of warranty is entitled to damages which will place him, so far as possible, in the position in which he would be if the representation had been true. ${ }^{108}$ In the case of a breach of warranty of quality in a contract of sale this is specifically provided for by s.53(3) of the Sale of Goods Act 1893. Where the warranty in-

104 Sarat Chunder Dey v. Gopal Chunder Laha (1892) L.R. 19 Ind. App. 203 (P.C.).

iss Suenson v. Payne (1945) 71 C.L.R. 531.

106 See Swan v. North British Australasian Co. (1863) 2 H.\&C. 175.

10: There is one type of case-'conventional' estoppel or estoppel by agreement, where no representation is required, but the parties simply agree to regulate their rights on the basis of certain assumed facts (see Ferrier v. Stewart (1912) 15 C.L.R. 32; Grundt v. Great Boulder Pty. Gold Mines Ltd. (1937) 59 C.L.R. 641). Such cases are governed by their own rules and are not strictly speaking cases of estoppel by representation at all; in fact they have no real connection with the estoppel by representation cases.

108 Yet this is not apparently the correct measure where a principal sues his agent for loss accruing from a misrepresentation made by the agent: Salvesen \& Co. v. Rederi Aktiebolaget [1905] A.C. 302. The reason for this is not clear. 
duces a contract between representor and representee this is a perfectly natural result because the whole approach of the law is to treat the warranty as part of the bargain; and the normal measure of damages in contract is intended to compensate the plaintiff for loss of (or breach of) the bargain. The plaintiff has not got what he bargained for, and is entitled to damages which will give him what he bargained for.

But it is, of course, well known that the measure of damages for misrepresentation in tort is not the same. Here the representee's complaint is not loss of bargain; he complains because he has suffered loss as a result of being induced to act on the representation. Accordingly the damages here are merely intended to place him in the position in which he would have been if he had not acted on the misrepresentation, and not to place him in the position in which he would have been if it were true. The distinction appears clearly from the following situation: ${ }^{109}$

A sells shares to $B$ and gives $B$ a (stolen) share certificate and a signed transfer which is not registered by $B$. The company makes a call on the shares which has to be paid by $A$ who is purporting to be the owner. A demands payment of the calls from $B$. Before payment $B$ insists that he be registered, and the company accordingly registers him and issues him with a certificate. In reliance on the certificate he pays $A$ the amount of the call. It is later discovered that $A$ had no title to the shares, and the company removes B's name from the register.

Now it is clear that the company has represented to $B$ that he is the owner of the shares, that it intends or expects him to act on that representation, and that he has done so. The question then is whether $B$ can recover damages from the company (1) for his loss, i.e. the amount of the calls paid to A, or (2) for the full value of the shares. The former is the tort measure, the latter is the warranty measure. In fact the Courts have had no hesitation in giving the warranty measure of damages in cases of estoppel. ${ }^{110}$ They have treated this as naturally following from the basic principle that the representee is entitled to sue on his 'independent cause of action' as though the representation were true. But the net result is that estoppel seems even more akin to warranty than it does to fraud or negligent misrepresentation. ${ }^{111}$ In some cases the result of this is that action to the detriment of the representee which causes only a very minor loss gives the representee the right to claim very much higher damages. ${ }^{112}$

The strange result of all this is that it seems at least theoretically possible for a representee to obtain damages for misrepresentation via

\footnotetext{
109 See Hart v. Frontino (1870) L.R. 5 Ex. 111.

"10 See Spence-Bower, supra, n. 80 at 107.

"II It may be that in fact the distinction between these two measures of damages should not strictly follow the tort/contract line: it is perhaps not just a question of bargain, but of expectations. If $X$ induces reasonable expectations in $Y$, perhaps $Y$ is entitled to have those expectations realized whether or not he bargained for them, provided that he has acted on them. In America there has been much discussion of a similar problem, viz., whether a promisee is entitled to damages for loss of bargain where the promise is enforceable because he has acted upon it, but there is no counter-promise, and therefore strictly no bargain. See for a good recent discussion (1970) 37 University of Chicago Law Review 559. In England it has never been doubted that insofar as such promises are enforceable the promisee is entitled to the contract measure of damages-see, e.g. Carlill v. Carbolic Smoke Ball Co. [1893] 1 Q.B. 256, where the plaintiff recovered the promised $£ 100$, and not just the cost of the smoke ball.

112 See, e.g. Greenwood v. Martin's Bank, supra, where the plaintiffs representation (by silence) led to in. action by the bank as a result of which they took no steps to sue the plaintiffs wife before she died. But they may in fact have recovered very little from such an action.
} 
estoppel without having to prove the additional requirements of warranty. No 'intent' to warrant need be proved, and none of the policy factors to which we have referred need be present. In short there seem to be no 'control devices' by which the Courts can limit liability of this kind if they find it unjust, as they can with a claim openly based on warranty. Yet in practice no claim for damages via estoppel seems to have succeeded except in circumstances in which it would be quite reasonable to find a warranty to be present. And it is not difficult for a Court to refuse damages via estoppel by holding that (e.g.) the representation was ambiguous ${ }^{113}$ or that the representee acted unreasonably in relying on it.

\section{ii. Warranty and Estoppel: two obvious differences}

Estoppel is (as we have seen) a remedy which allows the representee such relief as would be appropriate if the representation were true. Warranty primarily allows the representee to claim damages on the basis that the representation is false. But in this respect warranty is clearly the superior or higher remedy; there can, I think, be no doubt that whenever damages are recoverable for breach of warranty the representee could rely on estoppel in the alternative if he chose to do so. All the ingredients of estoppel are necessarily present in a case of warranty, viz., a statement of fact, acted upon by the representee, the intention, or at least reasonable probability that he would so act, and detriment to him from so acting. But as we have seen, warranty requires in addition other factors, conventionally treated as the "intent to warrant'. Therefore every case of warranty could be treated as a case of estoppel whereas the converse is clearly not true.

Therefore the two distinctions between warranty and estoppel are-

1. Warranty has additional requirements over and above those needed for estoppel.

2. Warranty provides the representee with a choice of two remedies, while estoppel is limited to one.

The question which now arises is whether there is a rational connection between these two distinctions. Are these distinctions due to a series of accidental chances in the historical development of the law, are they mere quirks, or is there some sensible foundation to them? If we were to start with a clean slate (and the Law Commission's proposals for codifying the law do start with a fairly clean slate) would we retain these distinctions or sweep them away? Is there any policy reason why every set of facts sufficient to support an estoppel should not be treated as a warranty giving the representee the choice (where this is in fact possible) of either suing for damages on the basis of the falsity of the representation, or claiming whatever relief would be appropriate if it were true?

\section{iii. Warranty and Estoppel: are the distinctions worth retaining?}

In favour of retaining the present distinctions it could be argued that the remedy of estoppel is naturally a secondary or inferior remedy to the remedy of damages; therefore less justification needs to be shown for this remedy than for treating a representation as a warranty. The mere making of a false statement with knowledge that it

"1a See Low v. Bouverie, supra, where the Courts' obvious views as to the merits of the case were given effect to by an extraordinary finding of fact. 
is likely to be acted upon is a good ground for regulating the rights of the parties by reference to the supposed facts. But if damages are sought from an innocent representor it can be argued that it should be necessary to go further, for example to show some benefit to him from the representee's conduct and some element of responsibility for ascertaining the truth of his statement. Are these arguments sound? Is estoppel a secondary or 'inferior' remedy to damages? Certainly this cannot be said of the remedy of specific performance for breach of promise with which I suggested estoppel has affinities. The answer seems to be that it is correct to treat estoppel as an inferior remedy where it operates purely as a defensive device. It can be argued that it is rational policy to require less justification for giving a party a defence to an action, than for giving him an affirmative cause of action. Prima facie, it can be urged that some justification needs to be shown for disturbing the status quo: the onus of proof is on a party who starts legal proceedings. But a defence to an action is an attempt to maintain, not to upset, the status quo. The principal objection to this argument is (as we have seen) that in many of the principal situations in which estoppel by representation is applied it does in fact assist the representee to take the initiative and obtain damages for the misrepresentation. In the share certificate cases, the bill of lading cases and the warehouse keeper cases the plaintiff can in fact recover damages via estoppel for the misrepresentation. Similarly where a person claims to have acquired a title to goods by estoppel he is using estoppel to disturb the status quo and not to maintain it, at least where he has not obtained possession of the goods. ${ }^{114}$

But there may, in turn, be an answer to this objection. It is, I think, strongly arguable that many of the typical cases of estoppel in which the representee is enabled to recover damages at present have really got into the wrong legal category. These cases could, and perhaps should, be treated as warranty cases pure and simple. Little doctrinal difficulty would be met by following this course, and in some cases, indeed, it seems purely accidental that this is not how the law has actually developed. ${ }^{115}$ For instance, the statement in a bill of lading that the goods are 'shipped in apparent good order and condition' could (it seems) quite easily be treated as a warranty to the endorsee of the bill of lading. In fact an argument to this effect was put to the Court in the first of these cases ${ }^{116}$ but was rejected by Channell $\mathrm{J}$. for a reason which now seems unsound; he thought that if these words were contractual they must be part of the original contract of carriage which was transferred to the endorsee of the bill of lading under the Bills of Lading Act 1855. In that event the words would have had no effect because the original shipper must have known that the goods were not in apparent good order and condition and could not have sued for breach of warranty; therefore (reasoned Channell J.) the endorsee

11 As in Mercantile Credit Ltd. v. Hamblin, supra, where the claim failed.

11s In Freeman v. Cooke, supra, it was in fact suggested that most cases of estoppel would be cases of contract or licence, and in Cornish v. Abington (1859) 4 H.\&N. 549 it was even said that the rule of estoppel only applied where this was so: 'No doubt, unless the representation amounts to an agreement or licence, or is understood by the party to whom it is made as amounting to that, the rule would not apply', per Pollock C.B., at 555. Moreover, as I have argued elsewhere, this is precisely what did happen with promises. The whole purpose of Jorden $v$. Money, supra, was to treat a promise acted on by the promisee as a contract and not an estoppel. Later developments have, however, distorted this conclusion.

116 Compania Naviera v. Churchill \& Sim [1906] 1 K.B. 237, though (it seems) without the assistance of the Sheffield Corporation case which had been decided a few months earlier. 
of the bill of lading would not have been able to sue for breach of warranty either. But this is fallacious. If it is sound policy to give the endoresee of the bill of lading a remedy, the words 'shipped in apparent good order and condition' could be treated as a warranty addressed directly to an endorsee of the bill of lading; the endorsee could then rely on it in his own right, and not as transferee of the original contract. ${ }^{117}$ If, on the other hand sound policy should deny the endorsee the right to sue where the original shipper cannot, the estoppel decision is just an evasion of the earlier part of the judgment.

In later cases Channell J.'s reasons for not treating the case as one of warranty seem to have been forgotten and the Courts have fastened on another part of his judgment in which he said:118

The words 'shipped in good order and condition' are not words of contract in the sense of a promise or understanding. The words are an affirmation of fact...

This seems plain enough; the words are a representation of fact, not a promise, but that does not mean they may not amount to a warranty. But in Silver v. Ocean S.S. Co. Ltd. ${ }^{119}$ it was said that Channell J. had decided that the words 'shipped in good order and condition' are not words of contract in the sense that they do not constitute a warranty. The result is that these words have ever since been treated as sufficient to raise an estoppel but not a warranty. There seems no justification for this. Every feature of warranty is present: statement of fact, intended to be acted upon, benefit to the shipowner ${ }^{120}$ and responsiblity for ascertaining the facts on the representor.

The same is, I believe, true of many other cases which are commonly treated as cases of estoppel. For example, consider the 'classic' case of Western v. Fairbridge:121 the plaintiff's husband wanted to borrow money on the security of some furniture and fittings which belonged to her. She made a statutory declaration that the goods belonged to her husband, and in reliance on this the defendant made a loan to the husband on the security of a bill of sale. The plaintiff was held estopped from asserting her title. But why could this not be treated as a case of warranty? Every element of warranty seems present, but it was plainly simpler and preferable for the representee to claim the relief appropriate on the footing that the statement was true (viz. a charge on the goods) than damages. In Brownlie v. Campbell ${ }^{122}$ Lord Blackburn virtually confessed his failure to see any distinction between cases in which damages are obtained via estoppel and cases of warranty.

'Most of the cases' he says '(the leading one is Burrowes v. Lock'23 and it is sufficient to mention that, though there were others) when looked at, if they do not absolutely amount to contract come uncommonly near it.'

He then stated the facts of Burrowes v. Lock and added that if that was not warranty or contract it was so uncommonly like it that I

\footnotetext{
117 That such a warranty is possible doctrinally seems confirmed by V/O Rasnoimport v. Guthrie [1966] 1 Lloyd's Rep. 1.

i18 Id. at 247 .

119 [1930] 1 K.B. 416.

120 Indirect benefit, of course, but very real; a shipowner who refused to issue bills of lading would soon find himself out of business.

121 [1923] 1 K.B. 667.

$1: 2$ (1880) 5 App.Cas. 925, 952-953.

$12: 5$ (1805) 10 Ves. 470.
} 
cannot make the distinction myself. Yet in Low v. Bouverie ${ }^{124}$ it was held that Burrowes v. Lock could only be supported as a case of estoppel and not as a case of contract.

In many of these cases the application of estoppel serves the representee perfectly well and nobody is ever likely to argue that such statements should be treated as warranties, but in any reform of the law the correct classification of such cases would assume greater importance. My suggestion, then is that cases of representation where the warranty elements are present should all be treated as cases of warranty. But it should then be recognised that what we now term 'estoppel by representation' is an alternative remedy open to the representee where the facts permit, i.e. where he would have some relief other than damages if the representation had been true. Estoppel would then cease to be a weapon of offence, and it would never be possible to claim damages for misrepresentation by way of estoppel. Such a claim would have to be based on warranty or fraud or negligence.

If this were done, it would remain only to consider whether there may not be other cases where estoppel could operate as a defence even though the statement is not actionable as a warranty, or for fraud or negligence. Thus, where the representor has no real interest in the action taken by the representee as the result of the representation, and where the representor has no special responsibility for ascertaining the truth of the statement, estoppel could still be used purely as a defence to an action. In this way it would operate as an extension of the principle that misrepresentation is a defence to an action for breach of contract, though not per se giving rise to a claim for damages. If this were done, estoppel without warranty could be left to perform a much more minor function than it does today: namely to offer a purely defensive role to a representee who is sued by the representor. In this limited sphere it would seem justifiable to impose 'strict liability' on the representor, and recognise a defence based on estoppel even though the additional factors which justify the creation of warranty-liability are not present. Thus even if the representor was wholly disinterested in the statement which he made and even if the representee may have had equal (or greater) responsibility for ascertaining the truth of the facts, the representation could give rise to a defence: the representee could claim to be entitled to treat the representation as true, even though he could not take the initiative and sue the representor for damages. I believe the role left for estoppel in this situation would be a small one for there are unlikely to be many situations in which a representor who has made representations with no real interest in, or responsibility for, what he says, will bring suit against the representee in connection with the same matter. But this need not cause any undue alarm. So long as estoppel is recognised as an alternative remedy available in all cases of actionable misrepresentation (whether for fraud, negligence or warranty) the Courts will have a sufficient armoury to enable justice to be done in most circumstances. There will then be few cases in which reliance will need to be placed on estoppel as a defence where there is no actionable misrepresentation.

124 Supra. Much of the present confusion in the law is traceable to this case where the Court took the notion of 'intent' to warrant a contract too seriously. The whole approach of the Court here is quite inconsistent with the Sheffield Corporation case. 